\title{
CFDによる実在地形周りの流れの計算 \\ Numerical Simulations of Flow around an Actual Complex Terrain
}

本章では, 実在する複雑地形を対象にした場合, 周辺 の風の流れの計算について, CFD 手法の現状と課題をま とめ, その計算事例を示すこととする。

\section{1. 複雑地形問題のための CFD 手法}

複雑地形における CFD 手法を以下のように現状と課 題をまとめることとする。複雑地形を対象とする場合に は，それに対応すべき計算予測方法を採用するべきであ り，それを実現するための情報を提示するものである。 実際に存在寸る地形は複雑な形態を有し，その千差万別 の大きさの部分で構成される。それを境界面として格子 生成するには，格子形状にも自由度が求められる。まず は任意形状に対する格子生成の方法として非構造格子と 一般座標系を取り上げ，それぞれの特徵をまとめる。さ らに, 近年, 各方面で普及している流れの計算コードを
解説する。特に使用が頻繁になっているものとして, オ ープンソースコードである OpenFOAM が取り上げられ る。その実態とその活用法あるいは使用にあたっての注 意点・課題について述べる。また, 風を乱流として捉え た場合, 乱流のモデリング技術が必要となるが, その代 表的モデルとして LES と RANS を取り上げ，地形のま わりの乱流場を対象としたときに発生する剥離流れに配 慮しながら, 乱流モデルの限界あるいは適用性を解説す るものとする。特に空間フィルタリングの概念が必要な LES では, 格子形状が変形するためその対応方法が課題 となる。また, CFD 手法は一般に限定された形状の計算 領域で実行されることになるが，その境界での取り扱い 方法について吟味する。地形を覆う植生は, 多雨の日本 の場合，比較的高い木々で構成される場合が多く，そう いった空隙を有する境界においては, 特別な境界条件,

$* 1$ 大林組 技術研究所

Technical Research Institute, Obayashi Corporation

*2 (株)風工学研究所

Wind Engineering Institute Co., Ltd.

*3 東京工業大学大学院 環境理工学創造専攻 教授

Professor, Department of Environmental Science and Technology, Tokyo Institute of Technology

*4 清水建設 技術研究所

Research Engineer, Institute of Technology, Shimizu Corporation

* 5 前田建設工業 技術研究所

Technical Research Institute, Maeda Corporation 
あるいは境界の取り扱い方法が求められる。ここでは, 一般的なものとして粗度長を用いた境界条件, さらに地 表の被覆形態の表現に融通性の高いことが期待される植 生キャノピーモデルを説明する。なお, LES を使う場合, 計算領域に流入してくる乱流場を設定する必要がある。 その乱流場を生成する方法についてもまとめる。今回は 比較的乱れの小さい海上を発達寸る乱流境界層について 検討している。さらに地形を解析対象とする場合, 限定 された計算領域に作用寸る気象学スケールの大気乱流構 造の取り扱い方法を考える必要がある。ここでは, 気象 学スケールから地形の工学スケールへの風の流れの接続 する方法について吟味する。

1. 1 解析手法 : 一般座標系と非構造格子

(小野佳之)

(1) 計算スキームと格子の特徴

複雑地形まわりの流れの解析を行う場合, 地形の起伏 による風速の増減や, 地表面からの剥離性状を的確に捉 えるために,一般に, 地表面の形状に境界を適合させた,

一般曲線座標格子や非構造格子が用いられる。

一般座標格子は, 格子が規則的に配列されている構造 格子の一つである。非圧縮性粘性流体の支配方程式であ る Navier-Stokes 方程式，および連続の式を，物理空間か ら計算空間に座標変換し, 有限体積法や有限差分法に基 づき離散化が行われる。一方, 非構造格子を用いる場合 は, 主に有限体積法が用いられ, 支配方程式をコントロ ールボリュームで積分し, グリーン・ガウスの方法を適 用して，離散化が行われる ${ }^{1)}$

構造格子は, 格子点が規則的に並んでいるため, 各方 向において多数の点を利用した高次精度差分スキームが 利用される。一方, 非構造格子は, 格子の配列に規則性 をもたない格子系であり, 一般に高次精度化は困難であ る。そのため, 計算の安定化のために導人される風上差 分は, 一次精度であることが多く, 比較的大きな数值粘 性が導入されるため注意が必要となる。

一般座標格子（構造格子）では, セルの形状は 6 面体 である。また, 格子が規則的に並んでいるため, 水平方 向の解像度を確保するためには, 地表面近傍ばかりでは なく上空の格子幅も細かく設定され，格子点数が増大寸 る傾向がある。

非構造格子のセルの形状はテトラ (四面体), ピラミッ ド (四角錐), ヘキサ (六面体), プリズム (三角柱), ポ リヘドラル (多面体) 等, 様々な種類がある。セルの形 状や格子幅の変化に対しての自由度が高く, 地表面付近
の解像度を合理的に確保できるという利点がある。

一般座標格子では, 二階の微分項は, ヤコビアンやメ トリックを用いて離散化が行われる。一方, 非構造格子 では, 二階の微分項の離散化において, 界面の法線ベク トルと, セル中心間のベクトルが一致しない場合, 陽的 な近似が困難となり，セル界面の風速や圧力（スカラー 関数）の勾配をグリーン・ガウスの方法や最小自乗法等 を用いて算出し，陰的な項を加えることで補正する方法 が用いられる。ただし，グリーン・ガウスの方法は，用 いる格子によっては一様な流れさえも保存できず, また, 最小自乗法は格子点の粗密状況により, 正・負の数值粘 性が導入され，計算の不安定化や，流れを鈍化されるこ とがあり注意が必要である ${ }^{2)}$

一般に，非構造格子では，風上差分の導入や，二階の 微分項の近似などにおいて数值粘性が導入される傾向が ある。一方，格子解像度を合理的に変化させることがで きるため, 構造格子に比べると, 地上付近に細かい格子 解像度を設定し, 数值粘性の影響を低減させた解析が行 われている。

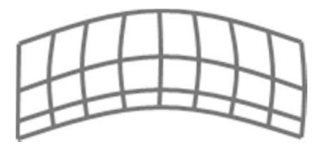

一般座標格子

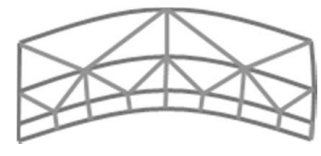

非構造格子
図 1 計算格子

（2）地図データと格子解像度

近年, 電子地図データが容易に入手できるようになり， また解像度も向上してきている。非構造格子を利用した 計算では, 一般に，市販のソフトを用いて格子生成が行 われる。ただし, 地図データの解像度に比べて, 計算で 用いる格子幅が大きくなると，現状とは異なる境界面が 自動的に生成されることがあり，注意を要する。

また, 地図データによっては, 地表面が滑らかに設定 されていない場合があり, あらかじめ地図データの補正 を行うか, 格子生成時に境界面のスムージング操作を行 うなどの修正が必要である。

参考文献

1) Versteeg, H. K., Malalasekera, W. , “An Introduction to Computational Fluid Dynamics, Finite Volume Method, second edition", Pearson Education Ltd, (2007)

2) 嶋英志,「勾配計算法の再検討と新手法について」, 第 41 回流体力学講演会/航空宇宙数值シミュレー ション技術シンポジウム,pp83-88,(2009) 


\section{2 解析手法 : OpenFOAM}

(丸山勇祐)

OpenFOAM (Open source Field Operation And Manipulation)は，オープンソースの数值流体解析ツール である。プログラムは C+十言語で書かれており，使用者 が必要に応じて中身を変更することができるようになっ ており，世界的に広く活用されている。支配方程式は， 連続の式とナヴィエ・ストークス方程式で与えられ，セ ル中心に変数が配置された有限体積法により支配方程式 を離散化している。

OpenFOAM の利点は，以下のことがあげられる。

(1)並列化計算の容易性 : ノード間通信を伴う並列計算プ ログラミングは煩雑化しがちであるが, OpenFOAM では どのような計算機においても容易に並列化ができ，並列 数に応じた計算の向上が見込まれる。

(2)非構造格子の採用: 非構造格子を採用していることか ら様々な形状に対しても格子を設定することができる。 snappyHexMesh 等のユーティリティが用意されており, 特に専門的な知識を持たずに非構造格子を生成できるよ うになっている。また，格子のフォーマットも公開され ており, 種々の格子生成ソフトから OpenFOAM 用の格 子が生成できるようになっている。最もよくつかわれて いる市販コードの一つである fluent の格子から OpenFOAM 用の格子を生成するユーティリティも用意 されており, 汎用性が高い。

(3)世界的に活用されているオープンソースコード : ソー スコードが公開されているため，ユーザーの仕様に合わ せてカスタマイズが可能である。言語も C++が用いられ ており，直観的に式等を簡単に変更することができるの も特徴であるといえる。このことからコードも改良され ていっており, ヴァージョンアップごとに便利なツール が増えている。また，世界中で利用されているため，イ ンターネット上の掲示板等が充実しており, 問題解決が スムーズにできる。

OpenFOAM の標準ソルバーには様々なものが用意さ れており，以下のような計算が可能である。

・非圧縮性流体の定常/非定常乱流解析

- 圧縮性流体の定常/非定常熱対流解析

- 流体・固体伝熱 解析

・混相流解析 など

複雑地形周りの流れの解析には非圧縮性流体の解析が 用いられ, 乱流モデルとしてはRANS (定常解析) やLES （非定常解析）が用いられる。

OpenFOAM には表 1 に示す RANS 乱流モデルや表 2 に
示すLES 乱流モデル等が標準で用意されている。

ここまで説明してきたように OpenFOAM の汎用性の 高さは特筆するべきものがあり，今後さらに利用が高ま ってくるものと考えられる。現状では，有限体積法の離 散化の問題, 非構造格子に伴う問題, 高次精度差分への 対応，数值粘性の問題等，不明な点が残されていること があげられているが，今後の改良と発展に対する期待の 方が大きいと考えられる。

表 1 RANS 乱流モデル（OpenFOAM）

\begin{tabular}{|c|c|}
\hline 非圧縮性RAS乱流モデル & incompressibleRASModels \\
\hline laminar & 層流用ダミ一乱流モデル \\
\hline kEpsilon & 標準の高Re $\kappa-\varepsilon$ モデル \\
\hline kOmega & 標準の高Re $\kappa-\omega$ モデル \\
\hline kOmegaSST & $\kappa-\omega-$ SSTモデル \\
\hline RNGkEpsiolon & $\mathrm{RNG} \kappa-\varepsilon$ モデル \\
\hline NonlinearKEShih & 非線形Shih $\kappa-\varepsilon$ モデル \\
\hline LienCubicKE & Lien cubic $\kappa-\varepsilon$ モデル \\
\hline qZeta & $\mathrm{q}$-とモデル \\
\hline LaunderSharmaKE & Laundew-Sharma 低Re $\kappa-\varepsilon$ モデル \\
\hline LamBremhorstKE & Lam-Bremhorst 低Re $\kappa-\varepsilon$ モデル \\
\hline LienCubicKELowRe & Lien cubic 低Re $\kappa-\varepsilon$ モデル \\
\hline LienLeschzinerLowRe & Lien-Leschziner 低Re $\kappa-\varepsilon$ モデル \\
\hline LRR & Launder-Reece-Rodi RSTM \\
\hline LaunderGibsonRSTM & 壁反射項付きLaunder-Gibson RSTM \\
\hline realizableKE & Realizable $\kappa-\varepsilon$ モデル \\
\hline SpalartAllmaras & Spalart-Allmaras 1 方程式混合距離モデル \\
\hline
\end{tabular}

表 2 LES 乱流モデル（OpenFOAM）

\begin{tabular}{|c|c|}
\hline 非圧縮性LES乱流モデル & incompressibleLESModels \\
\hline Smagorinsky & Smagorinsky モデル \\
\hline Smagorinsky2 & 3次元フィルタ付きSmagorinskyモデル \\
\hline dynSmagorinsky & ダイナミックSmagorinsky モデル \\
\hline homogeneousDynSmagorinsky & 同次ダイナミックSmagorinsky モデル \\
\hline dynLagragian & Lagrange型2方程式渦粘性モデル \\
\hline scaleSimilarity & スケール相似モデル \\
\hline mixedSmagorinsky & Smagorinskyとスケール相似の混合モデル \\
\hline dynMixedSmagorinsky & ダイナミックSmagorinskyとスケール相似の混合モデル \\
\hline kOmegaSSTSAS & 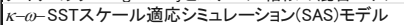 \\
\hline oneEqnEddy & $\kappa$ 方程式滑粘性モデル \\
\hline
\end{tabular}

1. 3 乱流モデル : LES

(野津剛)

Large eddy simulation (LES) では, 風速などの物理量 に 空間フィルターを施し, 格子で解像される GS (grid scale) 成分 と，解像できない SGS (sub-grid scale) 成分に分 離され, GS 成分の渦については直接計算し, SGS 成分 の渦についてはモデル化して計算される。なお，空間フ イルターには Gaussian フィルターやTop hat フィルター, Spectral cutoff フィルターなどが用いられる。

地形の問題の場合，一般に格子が一様でなくなり，さ らには格子形状が直方体でなくなることから，フィルタ 一幅の判定あるいはフイルター操作に係る誤差が発生す ることに注意しなければならない。

LES の基礎方程式としては，フィルター操作を施した 連続の式およびN-S 方程式が用いられ，以下のように示 される。

$$
\frac{\partial \bar{u}_{i}}{\partial x_{i}}=0
$$




$$
\begin{aligned}
& \quad \frac{\partial \bar{u}_{i}}{\partial t}+\frac{\partial \bar{u}_{i} \bar{u}_{j}}{\partial x_{j}}=-\frac{1}{\rho} \frac{\partial \bar{p}}{\partial x_{i}}-\frac{\partial \tau_{i j}}{\partial x_{j}}+v \frac{\partial^{2} \bar{u}_{i}}{\partial x_{j} x_{j}} \\
& \tau_{i j}=\overline{u_{i} u_{j}}-\bar{u}_{i} \bar{u}_{j} \\
& \text { ここで, } \tau_{i j} \text { はSGS 応力項と呼ばれ, GS 成分のみを用 }
\end{aligned}
$$

いてモデル化する必要がある。モデル化の方法としては Smagorinsky モデル, スケール相似則モデル, さらには 両モデルを組み合わせた混合モデルなどが挙げられる。 混合モデルの場合, 洞粘性以外の項も含まれることにな ることから, SGS 成分から GS 成分へのエネルギー輸送 (逆カスケード現象)を表現することも可能である。 主なモデルを以下に示す。

\section{(a) Smagorinsky モデル}

渦粘性近似に基づき, SGS 応力項を以下のように示す。

$$
\tau_{i j}-\frac{1}{3} \delta_{i j} \tau_{k k}=-2 v_{e} \bar{S}_{i j}
$$

$\bar{S}_{i j}$ はひずみ速度テンソル $\left(\bar{S}_{i j}=1 / 2\left(\bar{u}_{i, j}+\bar{u}_{j, i}\right)\right)$, $v_{e}$ は SGS 渦動粘性係数と呼ばれ, 以下のように表すこ とができる。

$$
\begin{aligned}
& v_{e}=\left(C_{s} \Delta\right)^{2}|\bar{S}| \\
& \text { ここで, }|\bar{S}|=\left(2 \bar{S}_{i j} \bar{S}_{i j}\right)^{1 / 2}, \Delta \text { LES のフィルター幅, }
\end{aligned}
$$

$C_{s}$ は Smagorinsky 定数である。 $C_{s}$ の值は一様等方乱流 では理論值（0.17）が推奨されるが，流れ場の種類によ って最適值が異なるため $(0.10 \sim 0.25$ の值), 複雑乱流場 では 1 つの值に決めることが難しい。

また, 速度勾配が大きな壁面近傍では, $v_{e}$ を過大評価 してしまうので, これを打ち消すために減衰関数を導入 して補正をおこなう必要がある。通常は van Driest 関数 が良く用いられる。

\section{(b) スケール相似則モデル（Bardina モデル）}

LES の SGS 成分 $f^{\prime}=f-\bar{f}$ の両辺にフィルターをか けると $\bar{f}^{\prime}=\bar{f}-\overline{\bar{f}}$ となる。これは, SGS 成分の比較的大 きなスケールの変動と GS 成分の比較的小さなスケール の変動が相似であることを意味する。この考えに基づい て SGS 応力を以下のように示す。

$$
\tau_{i j}=\overline{\bar{u}_{i} \bar{u}_{j}}-\overline{\bar{u}}_{i} \overline{\bar{u}}_{j}
$$

スケール相似則モデルは, Smagorinsky モデルよりも DNS 結果と相関が高いといわれているが, 散逸性がない ので計算が不安定となる。そのため, Smagorinsky モデ
ルと組み合わせて使われることが多い。

(c) ダイナミック SGS モデル

Smagorinsky モデルはモデル定数 を1つの值に決める のが困難であることが久点の 1 つである。その欠点を解 消寸るために $C_{s}$ を変数と考え, 流れ場の情報 (GS 成分) から $C_{s}$ を動的に決めるモデルがダイナミック SGS モデ ルである。このモデルは, Smagorinsky モデル, スケー ル相似則モデルに対し，フィルターを二重化することに より, モデル定数 $C_{s}$ を動的に算定することが可能となる。 また, Cs は流れ場に応じて決定されることから乱流粘性 の過大評価がなくなり, Smagorinsky モデルで必要であ った壁面近傍での減衰関数の導入が不必要になる。

\section{4 乱流モデル : RANS}

(岸田岳士)

日本の地形の起伏は，急峻な勾配を有していたり谷と 尾根が繰り返していたりかなり複雑な形態となっており, そうした地形上の流れは衝突流や剥離を伴うなど複雑な 乱流場となることが予想される。こうしたケースでは,

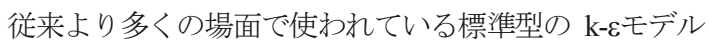
では予測精度が確保できないことが想定される。本節で は，こうしたケースでも予測精度の確保が期待される修 正型の RANS モデルについて紹介寸る。

標準型の k-Eモデルは様々な分野で活用され実績ある 乱流モデルの一つであるが，予測対象とする流れ場によ っては精度が確保できないことがある。標準型の k-£モ デルは簡単のために変動成分の非等方正を無視して定式 化されている。そのため, 非等方性の強い流れ場では予 測精度が低下寸ることが知られている。特に, 主流方向 に対して回転成分の 2 次流が生じるような流れ場では線 形モデルである標準型の $\mathrm{k}-\varepsilon$ モデルでは適切に予測する ことができない。予測対象とする日本の実地形を考えた 場合, 3 次元的に複雑な起伏を有し, 剥離を伴うような 急峻な起伏があるような場合もあり，そういった場所の 流れ場は非等方性が強く 2 次流と同じような回転成分の 流れのパターンが発生するようなことも想定されるため, 標準型の k-єモデルでの予測には限界がある。

様々な提案がされている RANS モデルのなかで, 非線 形モデルである shih $^{1)}$ の乱流モデルはこうした問題が解 消され予測精度の向上が期待できる乱流モデルの一つで ある。Shihのモデルでは(1)式に示すようにレイノルズ応 力をモデル化する。 


$$
\rho \overline{u_{i}^{\prime} u_{j}^{\prime}}=\underbrace{\frac{2}{3} \rho k \delta_{i j}-2 C_{\mu} \rho \frac{k^{2}}{\varepsilon} S_{i j}}_{\text {線形渦粘性型モデルの項 }}+\underbrace{2 C_{2} \rho \frac{k^{3}}{\varepsilon^{2}}\left(-S_{i k} \Omega_{k j}+\Omega_{j k} S_{k j}\right.}_{\text {非線形の付加項 }})(1)
$$

Shih のモデルが標準型の k-\&モデルと大きく異なるのは 以下の 2 点である。

(1)ひずみ速度テンソル $S_{i j}$ と渦度テンソル $\Omega_{i j}$ の積からな る非線形項を加えることにより，レイノルズ応力の非 等方性の再現を可能にしている。

(2)標準型 $\mathrm{k}-\varepsilon$ モデルの場合には $C_{\mu}=0.09=$ 一定值とするが,

Shih のモデルの場合には以下のように算出する。これ により, 流れの Realizability の条件が満たされること となる。

$C_{\mu}=\frac{1}{6.5+A^{*}{ }_{s}^{*}(k / \varepsilon)}$

$C_{2}=\frac{\sqrt{1-9 C_{\mu}^{2}(S k / \varepsilon)^{2}}}{1+6 S \Omega\left(k^{2} / \varepsilon^{2}\right)}$

$S=\sqrt{S_{i j} S_{i j}} \quad S_{i j}=\frac{1}{2}\left(\frac{\partial \bar{u}_{i}}{\partial x_{j}}+\frac{\partial \bar{u}_{j}}{\partial x_{i}}\right)$

$\Omega=\sqrt{\Omega_{i j} \Omega_{i j}} \quad \Omega_{i j}=\frac{1}{2}\left(\frac{\partial \bar{u}_{i}}{\partial x_{j}}+\frac{\partial \bar{u}_{j}}{\partial x_{i}}\right)$

$U^{*}=\sqrt{S_{i j} S_{i j}+\Omega_{i j} \Omega_{i j}}$

$A_{s}{ }^{*}=\sqrt{6} \cos \phi \quad \phi=\frac{1}{3} \arccos \sqrt{6} W^{*}$

$W^{*}=\frac{S_{i j} S_{j k} S_{k i}}{S^{3}}$

ここで, 乱流エネルギー $\mathrm{k}$ およびエネルギー散逸率をに ついては各々の輸送方程式を解いて求めることとなるが, 標準型の $\mathrm{k}-\varepsilon$ モデルではよどみ点において乱流エネルギ 一 $\mathrm{k}$ が過剩に生成されることが問題点の一つとして知ら れており, 急峻な地形を対象とした解析ではこういった 問題も影響があると想定される。そこで本報では(3)式〜 (6)式に示すKato-Launder補正を併せて適用することとし た。

$\mathrm{k}$ の基礎方程式

$\frac{\partial \rho \bar{u}_{j} k}{\partial x_{j}}=\frac{\partial}{\partial x_{j}}\left[\left(\mu+\frac{\mu_{t}}{\sigma_{k}}\right) \frac{\partial k}{\partial x_{j}}\right]-\rho \overline{u_{i}^{\prime} u_{j}^{\prime}} \frac{\partial \bar{u}_{i}}{\partial x_{j}}-\rho \varepsilon$

生産項 $\mathrm{P}_{\mathrm{k}}$ は以下のように示される。

$P_{k}=-\rho \overline{u_{i}^{\prime} u_{j}^{\prime}} \frac{\partial \bar{u}_{i}}{\partial x_{j}}=v_{t} S^{2}$

$S=\sqrt{\frac{1}{2}\left(\frac{\partial \bar{u}_{i}}{\partial x_{j}}+\frac{\partial \bar{u}_{j}}{\partial x_{i}}\right)^{2}}$

Kato-Launder 補正は, 渦度スケール $Q$ がよどみ点付近
で小さくなることより, (4)式の $P_{k}$ の評価式に以下のよう に渦度スケール $Q$ を導入するモデルである。

$P_{k}=v_{t} S \Omega$

$\Omega=\sqrt{\frac{1}{2}\left(\frac{\partial \bar{u}_{i}}{\partial x_{j}}-\frac{\partial \bar{u}_{j}}{\partial x_{i}}\right)^{2}}$

1) Shih, T.H. , et al. , "A new Reynolds stress algebraic equation model", Computer methods in applied mechanics and engineering, 125, pp. 287-302, (1995)

1. 5 地表面境界処理 : $\mathrm{z}_{0}$ 型対数則 (岸田岳士)

日本の地形には樹木などの風を遮る抵抗物があること が多く，地形上の風速を精度良く予測するにはそういっ た地表面の粗度の影響を考慮に入れて検討をする必要が ある。この場合, 地表面境界条件として no-slip 条件を適 用し, 地表の起伏や樹木など抵抗物になりうるものの形 状を篇密に再現して解析することは計算負荷が増大して 実用上はかなり困難である。そこで，ここでは地表面粗 度の影響を粗度長 $\mathrm{z}_{0} に よ り$ 取り込んだ $\mathrm{z}_{0}$ 型粗面対数則を OpenFOAM の LES 解析に適用した事例の紹介を行う。

OpenFOAM により壁面第一層の運動量を求める際に は, 壁面せん断応力 $\tau_{W}$ が必要となる。具体的な OpenFOAM の境界条件の設定では, 地表近傍での乱流粘 性係数 $v_{W}^{t}$ を設定することになるので以下にその方法を 示す。壁面近傍のセル中心点における壁面せん断応力 $\tau_{W}$ は(1)式にように示される。

$\tau_{W}=\mu \frac{u_{P}-u_{W}}{z_{P}}$

$\mu \quad$ : 粘性係数

$u_{P}$ : 地面付近第一七ル中心点の速度大きさ

$u_{W}$ : 壁面での速度 ここでは $u_{W}=0$

$z_{P}$ : 地面付近第一七ル中心点の地面からの距離

(1)式に摩擦速度 $u_{\tau}=\sqrt{\tau_{W} / \rho}$ を代入して整理すると(2) 式となる。

$$
\frac{\mu}{\rho}=\frac{z_{P}}{u_{P}} u_{\tau}^{2}
$$

$$
\rho: \text { 空気密度 }
$$

動粘性係数 $v=\mu / \rho$ なので

$$
v=\frac{z_{P}}{u_{P}} u_{\tau}^{2}
$$

となる。 
ここで, 地表近傍での有効動粘性係数 $v_{W E}^{t}$ は(4)式のよ うに示される。3)式に示した粘性係数は(4)式では有効乱 流動粘性係数 $v_{W E}^{t}$ に相当寸るので地表近傍の乱流動粘 性係数 $v_{W}^{t}$ は(5)式のように書ける。

$$
\begin{aligned}
v_{W E}^{t}= & v_{W}^{t}+v_{W} \\
& v_{W E}^{t}: \text { 地表近傍での有効乱流動粘性係数 } \\
& v_{W}^{t}: \text { 地表近傍での乱流動粘性係数 } \\
& v_{W}: \text { 地表近傍での動粘性係数 } \\
v_{W}^{t}= & \frac{z_{p}}{u_{P}} u_{\tau}^{2}-v_{W}
\end{aligned}
$$

地表近傍での乱流動粘性係数 $v_{W}^{t}$ を求めるためには, 摩擦速度 $u_{\tau}$ を評価する必要がある。

粗度長 $z_{0}$ を用いた粗面型の対数法則は(6)式のように 表わされる。

$$
\begin{aligned}
u_{p}=\frac{u_{\tau}}{\kappa} \ln \left(z_{p} / z_{0}\right) \\
\kappa: \text { カルマン定数 }(\kappa=0.41) \\
z_{0}: \text { 粗度長 }
\end{aligned}
$$

(6)式を変形すると(7)式となる。

$$
u_{\tau}=u_{P} \kappa \frac{1}{\ln \left(z_{P} / z_{0}\right)}
$$

(7)式を(5)式に代入して整理すると(8)式が得られる。 OpenFOAM の乱流粘性係数 $v_{W}^{t}$ に(8)式を適用寸ること になる。

$$
v_{W}^{t}=z_{P} u_{P} \kappa^{2}\left(\frac{1}{\ln \left(z_{P} / z_{0}\right)}\right)^{2}-v_{W}
$$

ここで, RANS の場合の境界条件についても紹介して おく。OpenFOAM のバージョンにもよるが，最近のバー ジョンでは $\mathrm{z}_{0}$ 型の対数則がデフォルトの機能である 「nutkAtmRoughWallFunction」で使用できるようになっ ている。ここでの取扱い方を以下に示す。

壁面近傍での流れは局所平衡にあり乱れのエネルギー と散冕がつりあっていると仮定すると(9)式の関係が得 られる。

$$
u_{\tau}=C_{\mu}^{1 / 4} k^{1 / 2}
$$

(5)式に(7)式および(9)式を代入して整理すると(10)式の ようになる。

$v_{W}^{t}=\frac{\kappa C_{\mu}^{1 / 4} k^{1 / 2} z_{P}}{\ln \left(z_{P} / z_{0}\right)}-v_{W}$
1. 6 地表面境界処理 : キャノピーモデル

(榎木康太)

大気境界層下部は, 陸面との種々の物理量の交換に伴 う乱れが発達した高レイノルズ数の流れ場である. 地表 面付近では, 粗面効果やスカラー輸送により非等方性の 強い乱流構造が形成・逸散され，地表に近づくほど渦の スケールは急激に減少する。大気境界層を対象として LES を実施しようとした場合，一連の過程をすべて解像 するために膨大な格子点が必要となり, 計算負荷の点か ら現実的ではない，そこで通常，壁近傍のグリッドスケ 一ル以下の乱流構造は, 摩擦項や生成項等の付加, 乱れ 長さスケールの修正といったモデルにより考慮される。 キャノピーモデルは，前者に分類され，様々なモデルが 提案されている ${ }^{1-5)}$. 粗視化された運動量保存則において 粗度要素による単位体積当たりの流体力 $f_{u, i}$ のモデル化 は多くのモデルで共通しており,以下のように表される.

$$
f_{u, i}=-C_{f} a \sqrt{u_{j}^{2}} u_{i}
$$

ここで， $u_{i}$ は $i(i=1 \sim 3)$ 方向成分流速， $C_{f}$ は抵抗係数で ある.また， $a$ は単位体積当たりの障害物の代表面積に 相当し, $\mathrm{m}^{-1}$ の次元をもつ. 粗度要素が植生の場合, $a$ は 葉面積密度と呼ばれ，単位体積中の葉の片側の総表面積 と定義される，実際の解析では，各パラメータは解析対 象に合わせた一般的な值を参考に設定される.

壁面第一セルにせん断力を与えるタイプのモデルと比 較した場合のキャノピーモデルの利点としては, キャノ ピー層上空の対数則領域における風速の鉛直分布の再現 性が良好であること ${ }^{1)}$ ，物理的な地表面と計算格子の壁 面が一致するためゼロ面変位の概念が不要, キャノピー 層内気流性状が考慮可能な点が挙げられる.

LES におけるキャノピーモデルは，地表面の粗面効果 をパラメタライズすることを目的とした地表面境界処理 としてのモデル ${ }^{1-2)}$ とキャノピー層内物理過程や上空大 気との相互作用の解明を目的としたモデル 3-0)に分類て きる.

前者のモデルでは, 粗度要素を含む格子において式(1) のみ考慮され, SGS(サブグリッドスケール)乱流統計量に 対する影響は陽に考慮されていない。このタイプのキヤ ノピーモデルは, Smagorinsky 型の乱流モデルと併用さ れることが多く, 主に工学的な LES を大気境界層スケー ルの解析へ適用寸る際に問題となる粗面効果のモデルと して提案され，地表面上空の平均風速分布の再現性向上 を目的としている。

一方, 後者のモデルでは, SGS 乱流統計量に関する輸 
送方程式において粗度要素による SGS 乱流エネルギー の生産や散冕の過程までモデル化されている.このタイ プのキャノピーモデルでは SGS 乱流エネルギー輸送式 のみ，もしくはSGS 乱流エネルギーの散冕率に関する輸 送式の両方を用いた乱流モデルが用いられる.このモデ ルは，気象の分野を中心に，植生と流体の相互作用によ る運動量・熱・水分・ $\mathrm{CO}_{2}$ 等に関する輸送過程の解明を 目的としている.

なお，前者のモデルは，運動量保存則だけを考慮すれ ばよく計算負荷が低く抑えられる利点があるが，一般的 にキャノピー層内やその直上の気流性状は Smagorinsky 型乱流モデルが前提とする等方性乱流と異なることが知 られている7゙ため, キャノピー層内や上端付近を対象と した流れ場の解析への適用には注意を要する。

また，前述のモデルの多くは，主に平坦地形上の均一 に広がる理想的なキャノピー層を対象として妥当性の検 証がなされている，一方，耐風設計で問題となるような 急峻な尾根や丘では，多くの場合その地表面は様々な形 態の植生で覆われており, 周辺の地形による流れ場と植 生群との相互作用の理解や粗度要素の不均一な分布の結 果生じる気流性状の把握が不可欠である. そのため, 個々 の樹木の樹種，葉や枝の季節的あるいは空間的な分布と いった実際の植生に関する詳細な情報を取得する手法の

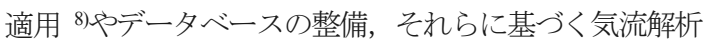
方法と検証方法の確立が求められる.

参考文献

1) Senocak, I., et al., Boundary Layer Meteorol., Vol.124, No.3, pp. 405-424, (2007)

2) Cassiani, M., et al., Boundary Layer Meteorol., Vol.126, No.3, pp. 433-460, (2008)

3) Shaw, R.H., Schumann, U., Boundary Layer Meteorol, Vol.61, No.1-2, pp.47-64, (1992)

4) 神田ら, 土木学会論文集, No.461, pp. 39-48, (1993)

5) Watanabe, T., Bound. Lay. Meteorol. Vol.112, pp.307-341, (2004)

6) 平岡, 日本建築学会環境系論文集, Vol.74, No.639, pp. 603-612, (2009)

7) Finnigan, J., "Turbulence in plant canopies", Annu. Rev. Fluid Mech., Vol. 32, pp. 519-571, (2000)

8) Hosoi, F. and Omasa, K., IEEE Trans. Geosci. Remote Sens., Vol.44, No.12, (2006)

\section{7 流入変動風}

(丸山勇祐)

(1) L E S における流入変動風の必要性

風荷重評価のために複雑地形の影響を評価するため のCF Dでは，平均風速の割増だけでなく乱れの影響ま で評価することが必要とされる。乱れを正しく評価する ためには，非定常な数值計算が必要であり，LESによる 計算が有効な手段となる。LES では，時々刻々解析を進 めていく非定常解析のため, 流入境界に与える風速変動 の影響が解析結果に大きく影響する。複雑地形上の流れ においては，地形の影響で流れが乱されるため流入に与 える乱れの影響は小さいとの考え方もあるが，本誌特集 の計算事例に示すように流入で与える乱れの影響が無視 できるようになるには，複雑地形上を $10 \mathrm{~km}$ 程度吹走さ せる必要がある。このような観点から乱れを含めた複雑 地形上の風速を正しく評価するためには，実際の乱流境 界層に近い流入変動風を計算領域の流入面に与えること が重要だといえる。

（2）流入変動風の生成方法

流入変動風を生成する方法には大きく分けて 2 つの手 法がある。1つは乱数等を用いて変動波形を生成する方 法ともう 1 つばライバー部で LES の計算を実施して 変動波形を生成する方法である。前者は，平均・変動・ スペクトル等の統計值に合わせて変動風を生成するが, 連続の式やナヴィエ・ストークス方程式に支配される物 理構造の再現が難しいことが課題として挙げられ，連続 の式を満たすようにダイヴァージェンスフリー操作を行 なったり 1)，実観測波形を条件とする 2)ことによって改 良されている。後者では, 変動風そのものを直接数值計 算で生成するものであり，支配方程式を満足した変動風 が得られるが，計算負荷が大きくなることが問題として 挙げられてきた。しかし，近年の計算機能力の向上や, 記憶媒体の低コスト・大容量化によりいったん計算した ものを容易に保存できるようになったことから，最近は 数值計算を用いる方法が使われることが多くなってきて いる。数值計算で流入変動風を生成す方法としては，チ ヤネルで乱れを発達させる方法等が考えられるが，圧力 勾配を与える必要があることや乱れの発達に時間がかか ることから, Lund らの提案した準周期境界を用いる方法 3)が多く用いられるようになってきた。Lund らの手法に よる流入変動風生成概要を図 1 に示す。この方法では, 境界層厚さを規定した流れを計算し，準周期境界に到達 した流れを流入面にリスケーリングして戻すことで，規 
定した境界層厚さの中で床面の摩擦に応じた乱れのみを 発達させている。野澤ら ${ }^{4}$ は，この方法を応用して粗面 上の流れに適合する方法を提案し, 片岡ら 5)は平均風速 のプロファイルを規定する方法を提案することで，勾配 の大きな乱流境界層に適用できるようにした。後節で示 す計算事例において, OpenFOAM を使った計算には Lund らの方法で生成した流入変動風を, 一般座標系を用 いた計算には片岡らの方法で生成した流入変動を用いて いる。

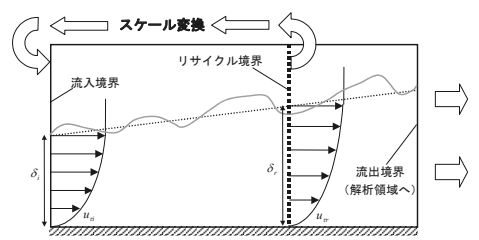

図 1 Lund ${ }^{3)}$ の手法による流入変動風生成概要

\section{(3) OpenFOAM の計算に用いた流入変動風}

OpenFOAM を用いた計算事例（いちき串木野・白滝山） の計算に用いた流入変動の特性をここに示す。流入変動 風はLund らの手法に基づいて生成している。図 2 に滑 面用, 図 3 に粗面用に生成した流入変動風の鉛直分布特 性を示す。滑面用は粗度区分 II, 粗面用は粗度区分IVの 気流に対応している。

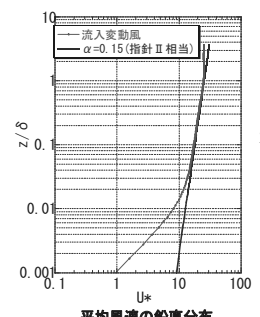

平均風速の鉛直分布

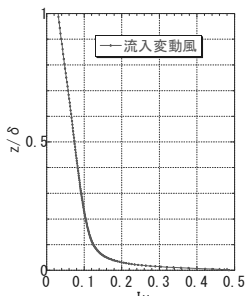

乱れ強さの鉛直分布

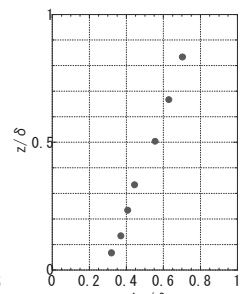

乱れのスケケール

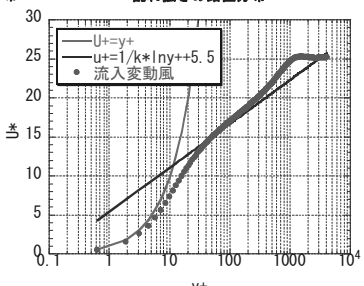

$\mathrm{y}+$

図 2 流入変動風の鉛直分布（滑面用）
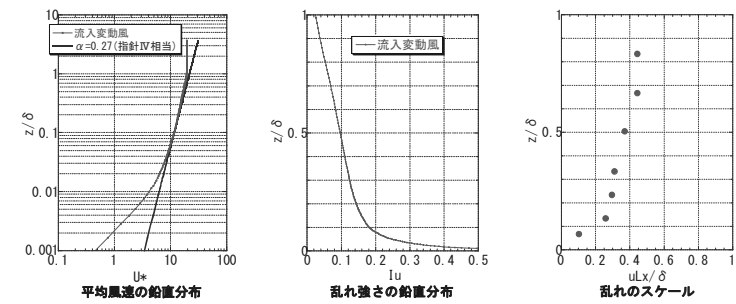

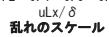

参考文献

1) 近藤 宏二, 持田 灯, 村上 周三, 土谷 学, 「乱流境界 層を対象とする LES のための流入変動風の生成一風 洞実験に基づくクロススペクトルマトリクスのモデ ル化一」, 日本建築学会構造系論文集, 第 509 号, pp. 33-40, (1998)

2) 丸山 敬, 盛川 仁，「乱流境界層内の実測データを条 件とする風速変動の数值シミュレーション」, 第 13 回風工学シンポジウム, pp. 573-578, (1994)

3) Lund, T. S., Wu, X., and Squires, K. D., "Generation of turbulent inflow data for spatially-developing boundary layer simulations", Journal of Computational Physics, No.140, pp. 233-258, (1998)

4) 野澤 剛二郎, 田村 哲郎, 「ラフネス上に空間発達す る乱流境界層の LES と変動風の評価」, 日本建築学 会構造系論文集, 第 541 号, pp. 87-94, (2001)

5) 片岡 浩人, 水野稔,「流入変動風を用いた 3 次元角 柱周りの気流解析」, 日本建築学会計画系論文集, 第 523 号, pp. 71-77, (1999)

1. 8 気象モデルとのハイブリッド

(榎木康太)

強風現象は, 一般的に地球規模の擾乱, 大地形, メソ スケールの擾乱, 局所的な地形, 周辺障害物等の要因が 複合的に重なり発生する場合が多い。そのため, 耐風設 計, 特に強風被害分析において重要な強風の推定には, これらの空間的・時間的にスケールの異なる個々の現象 に応じて適切に解析手法を選択し, 対象と寸る強風に対 して手法を組み合わせる必要がある。一般的には, メy スケール以上のスケールの現象は領域気象モデル(以下 気象モデル)によって, 局所的なマイクロスケールの現象 は工学モデル(CFD モデル)により考慮される. 気象モデ ルとしては, コロラド州立大学の RAMS ${ }^{1) や コ ミ ュ ニ テ ~}$ イーモデルとして有名な $\mathrm{WRF}^{2}$ 等が利用されている. 一 方, 工学モデルとしては, RANS 型のはく離の再現性, 後流域の解析精度等の問題を受け, 近年ラージエディー シミュレーション(以下 LES と表記)を適用する事例が増 加している.

一般的に, 気象モデルと LES による強風の予測手法に は LES の境界条件として気象モデルの解析值を用いる ネスティング手法と LES と気象モデルの解析を独立し て行い任意の参照点を介して両者の接続を行う参照点手 法の 2 つの方法がある.

前者では, 境界においてモデル間の差異を何らかの手

図 3 流入変動風の鉛直分布（粗面用） 
法により解消寸る必要がある，耐風設計適用の場面では LES の流入境界面においてアンサンブル平均が施されて いる気象モデルの諸物理量から LES の変動流入風を作 成する手法の開発が必要である，検討例としては，中山 $ら^{3)}$, 加藤ら ${ }^{4)}$, 内田ら ${ }^{5}$ による研究が挙げられ, いずれ においても LES 流入境界部付近における気象モデルに よる風速の鉛直分布に基づき, ディジタルフィルター6 や Lund ${ }^{7}$ 型の準周期境界条件により強風時の実大気の風 速の変動を模擬した変動流入風を LES の流入面に適用 寸ることで, 気象モデルと工学的な LES のモデル間の整 合性が図られている.

後者の手法では LES の流入条件として気象モデルの 解析值ではなく, 上流の地表面粗度区分に対応する速度 の鉛直プロファイルが用いられ, 気象モデルと LES のそ れぞれで独立した解析が行われる。 そして, 気象モデル の格子点と LES の格子点を一致させた参照点を設定し, その参照点で得られた気象モデルの解析結果に対して LES から得られた風速比を適用し, 解析領域内の任意の 点の風速を予測する。この場合, 異なるモデル間の接続 は直接的に考慮する必要がなく, 簡便な手法と言える.

田村ら ${ }^{8)}$ は, 高層建物屋上の解析対象の観測点高さ $240 \mathrm{~m}$ の上流点を参照点とし, 高層建物周辺の複数点の風速を 高い精度で予測可能なことを示した. 伊藤ら ${ }^{9}$ は, 平坦 な海上に位置する流入部に参照点を設定し, 海に面した 橋梁上の風速を予測している. この手法の問題点として は, 参照点の選定に任意性があるという点や高さによっ ては同じスケールの地形影響を両方のモデルで 2 重に考 慮してしまう点が挙げられる. 気象モデルで再現された 強風事象で再現された風速や温位等の物理量の分布に十 分留意して参照点の選定を行う必要がある.

何れの手法においても上述の検討例では, LES の流入 境界面は, 海上もしくは平坦地に設定されたケースが多 い. 任意地点における而風設計を想定した場合, 周辺地 形によっては海岸が近い風向で最も強風が生じるとは限 らない場合や計算負荷の都合上平坦な地形まで解析領域 が取れない場合も想定され, 強風推定手法の一般性とい う観点から解析領域の設定方法や地形を含む境界処理手 法に改善の余地がある. 関連して, 多風向解析対応や大 スケールの風向変化時の予測精度や大気安定度・転向力 等の影響の考慮などの課題も挙げられる. 一方で, 検証 に用いられる観測值の整備や処理方法も重要である. 地 表面近傍の観測值は, 周辺地形や周辺障害物の影響を強 く受けており， 1 点の観測值のみでは観測された強風の 時間・空間的スケールの判断がつきにくい. 特に, 風向
を限定した解析が行われることが多い工学的な LES で は, 解析対象時間帯の領域の代表風向の推定に多数の判 断材料が不可欠である. その他, 気象モデル側の物理過 程選択の妥当性や解析精度の検証も必要である. 気象庁 のゾンデの高層気象観測や全国のウィンドプロファイラ による上空風の観測など多数の地点の観測值に基づく総 合的な検証が求められる.

\section{参考文献}

1) Pielke et al., Meteor. Atmos. Phys., Vol.49, pp.69-91, (1992)

2) Skamarock, W. C., et al.. NCAR Technical Note, (2008)

3) 中山ら, 第 13 回非静力学モデルに関するワークショップ, (2011)

4) 加藤ら, 建築学会学術講演梗概集, pp. 765-766, (2013)

5) 内田ら, 風力エネルギー 34, No. 4, pp. 77-84, (2010)

6) 近藤, 飯塚, 建築学会環境系論文集, Vol.77, No.678, pp. 661-669, (2012)

7) Lund, T. S. et al., J. Comput. Phys.140, 233, (1998)

8) 田村ら, 建築学会構造系論文集, Vol.74, pp. 215-223, (2009)

9) 伊藤ら, 日本風工学会誌, vol.119, pp. 119-120, (2009)

\section{2. 複杂隹地形に関する計算事例}

実在する複雑地形まわりの風の流れ、 CFD を適用し たときの計算事例を示す。まず，検証用のデータとして 観測データについて述べる。これまで，多くはウインド ファームなどが計算対象とされ，観測データとしては, 風車のナセル上に設置された風速計により計測されたも のが用いられた。多くのポイントのデータが得られると いう利点があるが，計測值へのブレードの影響などが考 えられる。一方, NEDO のプロジェクトにおいては, 風 観測のために鉄塔を建てて, 超音波風速計も利用しなが ら計測された場合もある。ここでは, このように得られ た観測データを解説する。計算事例としては，このよう に得られた観測鉄塔での各成分の高周波数非定常データ と風車ナセル上で得られた多点の計測データの二つのサ イトを対象とした。前者については, 風速の変動性状も 含め, 地形の影響を受けた風を局所的に詳細な検討を行 うことになることに対し, 後者については, 複雑に水平 方向に広がる起伏上でどのような風速分布特性が表現さ れるかが概括的に吟味されることになる。なお，ナセル 上の計測は 3 杯型が用いられ，1秒ピッチで得られてい る時系列データに対し, 変動風速も検討対象とした。ま た, 計算法としては, 非構造格子を用いた LES と一般座 標系の LES を採用している。両者においてはメッシュ生 
成の特性上，地表からやや離れた位置での格子密度に差 が表れ，それによって風速データの鉛直分布の再現性に 違いが生じる可能性がある。なお，一般座標系において は, 気象モデルの解との接続も試みられている。

\section{1 鹿児島串木野の計算対象地形}

(佐々木亮治・岸田岳士)

本検討では, 図 1 に示寸鹿児島県のいちき串木野市 周辺を解析の対象とする。本サイトでは図中に青丸で示 寸 2 箇所の地点において, NEDO 次世代風力発電技術開 発事業により, 風向・風速などの観測が実施されている。 各観測地点に高さ約 $60 \mathrm{~m}$ の観測鉄塔が設置され, 鉛直方 向に複数点で風向・風速の測定が行われている。当該地 域周辺の最高高さは $500 \mathrm{~m} \sim 600 \mathrm{~m}$ 程度である。この観測 サイト周辺の地形の起伏をみると, 風向が南〜西〜北北 西にかけては上流側が海となっており, それ以外は複雑 な形状の地形が続いている。本検討では, 地形の起伏の 形態の違いや観測データを考慮して図 1 に示寸風向 SW および風向 NNW を解析の対象とする。この場合, 上流 側の流入境界面付近はともに海上となる。

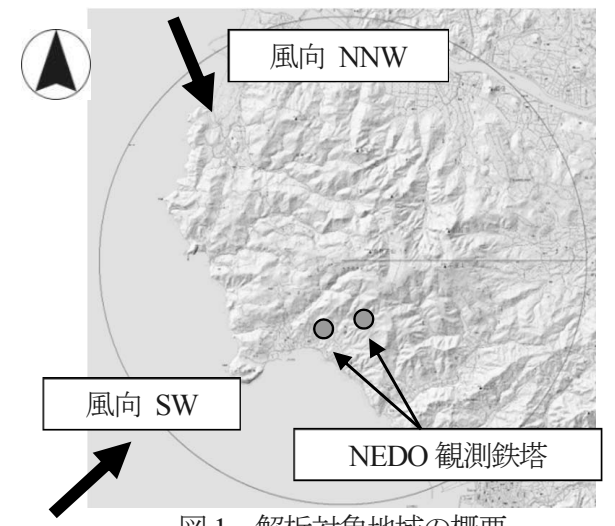

図 1 解析対象地域の概要

解析対象地点周辺の航空写真を図 2 に示寸。対象地点 の周辺は起伏に富んだ山岳地帯となっており, 航空写真 を見ると大部分が森林で覆われている様子がわかる。特 に，本検討で解析を実施する風向 SW および風向 NNW については, 観測鉄塔より上流側の陸地部分はほとんど 森林となっている。観測鉄塔近傍の状況を図 3 に示す。 近傍の地形の起伏の形態は, 谷と尾根が繰り返していた り, 空間の開けた場所の近傍に高い樹木があったり, か なり高い樹木が密集していたりとかなり複雑な地表面の 被覆形態となっている。

観測鉄塔では 2 地点ともに, 地表面から高さ $30 \mathrm{~m}, 40 \mathrm{~m}$, $50 \mathrm{~m}$ およ゙ $58 \mathrm{~m}$ の 4 レベルで三杯型風速計により風速の
測定を行っている。また，それぞれ高さ $58 \mathrm{~m}$ では風向の 測定を矢羽根型風向計により実施している。測定期間と しては, 連続したデータが得られている 2009 年 3 月から 2009 年 10 月までを対象とする。西側の観測鉄塔の一番 高い $58 \mathrm{~m}$ における風速 $5 \mathrm{~m} / \mathrm{s}$ 以上の風配図を図4 亿示寸。 全体的には, 北寄りの発生頻度が高く, SSW や ESE 近 辺の頻度も高い。解析風向である SW およびNNW の発 生頻度も高いことが分かる。

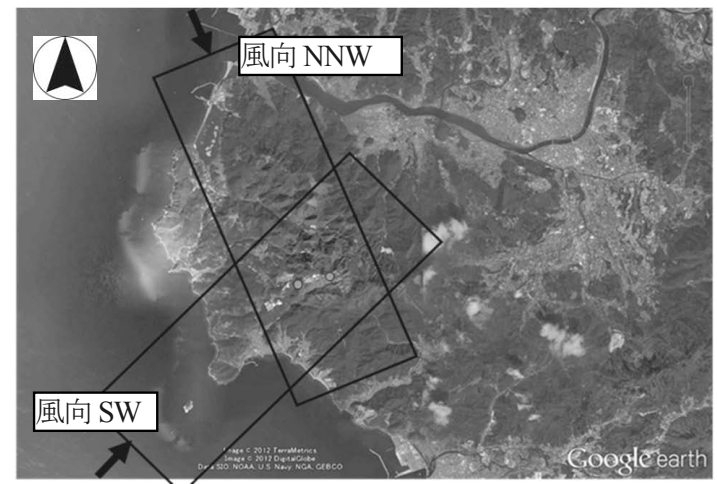

図 2 解析対象地域の航空写真
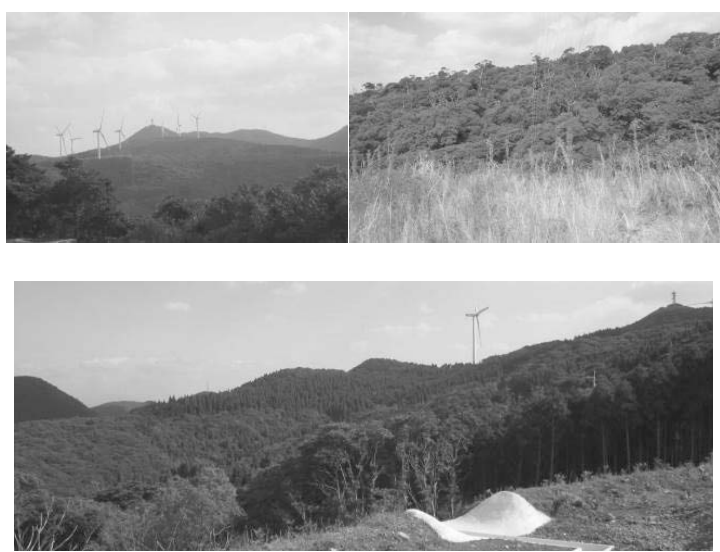

図 3 観測鉄塔近傍の状況

西側の観測鉄塔の一番高い $58 \mathrm{~m}$ の風向・風速記録を基 準として算出した風速比と乱れの強さの鉛直分布を, 図 5 と図 6 にそれぞれ示す。風速比は, 風速がある值以上 に大きくなると一定值に近づく傾向となることが経験的 に知られている。本検討では, 基淮点での風速を $5 \mathrm{~m}$ 以 上および $7 \mathrm{~m}$ 以上として算出した結果, 両者はほぼ一致 することが確認できた。図 5(a)より, 風向 SW では, 鉛 直分布の定性的な形状は变化せずに東側の風速比が西側 より増速して分布がシフトしている。一方，図 5(b)の風 向 NNW では，鉛直分布の定性的な傾向がかなり異なっ ていることがわかる。これは，風向により上流側の地形 の起伏形態の影響を受けて，観測鉄塔一流入寸る風速の 


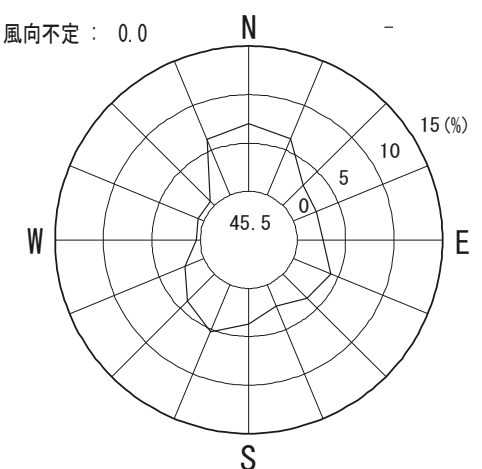

図 4 西側観測点の地上 $58 \mathrm{~m}$ における風速 $5 \mathrm{~m} / \mathrm{s}$ 以上の 風配図 (2009 年 3 月 10 月)

(円内の数值は風速 $5 \mathrm{~m} / \mathrm{s}$ 未満の割合)

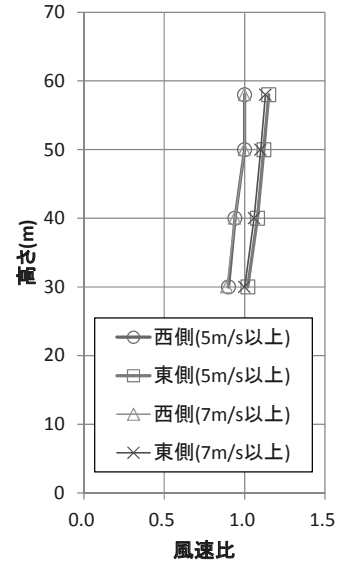

(a) 風向 SW

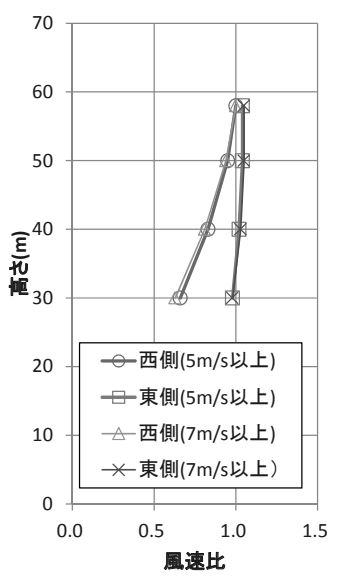

(b) 風向 $\mathrm{NNW}$
図 5 風速比の鉛直分布 (西側観測点の地上 $58 \mathrm{~m}$ における風速で基準化)

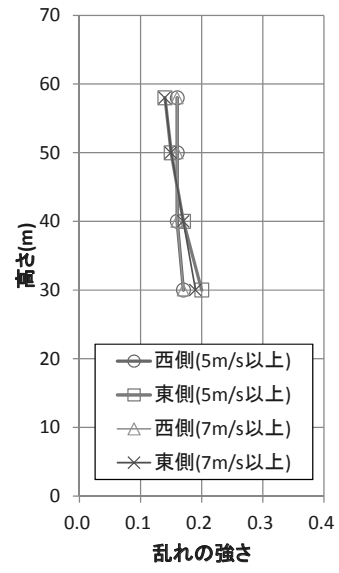

(a) 風向 SW

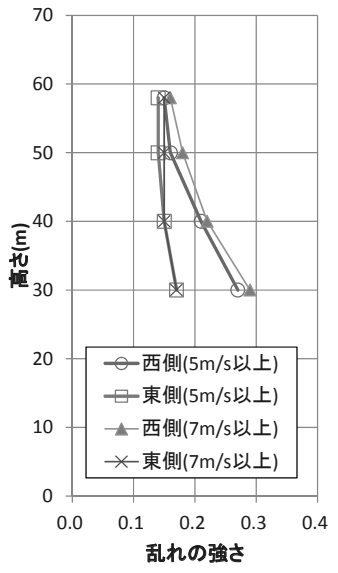

(b) 風向 $\mathrm{NNW}$
図6 乱れの強さの鉛直分布 (西側観測点の地上 $58 \mathrm{~m}$ における風速で基準化)
非構造格子を用いたオープンソースコードである OpenFOAm を用いて，鹿児島県いちき串木野市の高さ 500〜 600m 程度の山岳地を対象に LES を実施し, 実観測 データと比較した事例を紹介する。

(1) 計算格子の概要

計算に用いた非構造格子の生成方法の概要を簡単に示 す。計算用の地形は, 図 1 に示すように E-pole（NEDO 観測点) 近傍を中心に半径 $7 \mathrm{~km}$ の範囲を国土地理院発行

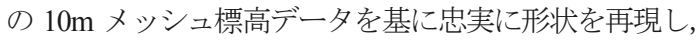
半径 $9 \mathrm{~km}$ の地点で高さが $0 \mathrm{~m}$ となるように 7〜 $9 \mathrm{~km}$ の範 囲にテーパーをつけている。円形領域を抽出しテーパー を周辺につけたのは，全風向のモデルが容易に生成でき るようにすることと, 流入変動風の流入高さを明確にす るためである。今回の計算では，出現頻度の高い風向 NNW を対象としていることから, 図に示すように地形 の中心から長さ $20 \mathrm{~km} \times$ 幅 $4 \mathrm{~km} \times$ 高さ $10 \mathrm{~km}$ の領域を切り 出し，その中に計算格子を生成した。

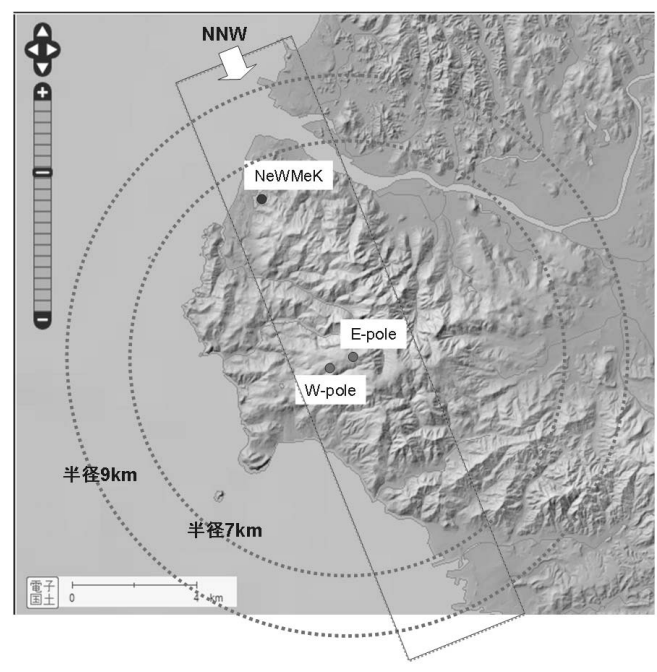

困 1 計算対象地形及び計算領域

困 2 に計算に用いた格子の概要を示す。計算には非構 造格子系の OpenFOAM を用いるため, 六面体要素（へ キサ）を基本とし，テトラ要素，ピラミッド要素，プリ ズム要素を組み合わせた非構造格子を使用している。領 域内高さ方向に 3 つボックスと解析中心周りに $1 つ の$ 円柱を設け，それぞれの領域の格子幅が 2 倍ずつリファ イン（格子解像度が 2 倍）されるようにし，解析中心の 地表面近傍では約 $10 \mathrm{~m}$ 間隔の格子となっている。また地 表面に沿っては 3 層の境界層格子を設置している。この 
格子は, 床面境界条件に $\mathrm{z} 0$ 型対数則の壁関数を適用する ことを前提として作成しており, 床面第 1 層が対数則領 域（レイノルズ数は風洞実験相当のものを使用）になる ように格子厚さを $5 \mathrm{~m}$ 程度としている。
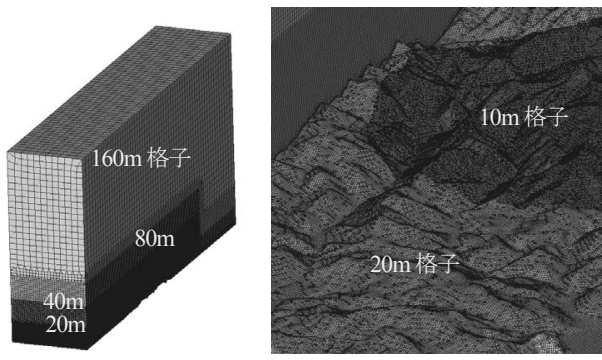

図 2 格子分割の概要（非構造格子：風向 NNW）

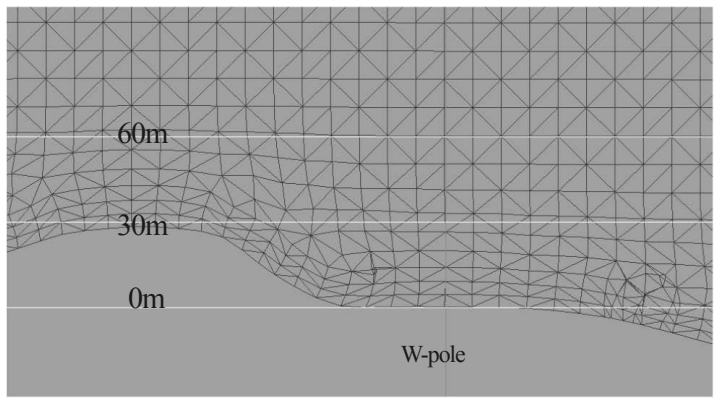

（a） $\mathrm{z} 0$ 型対数則壁関数用

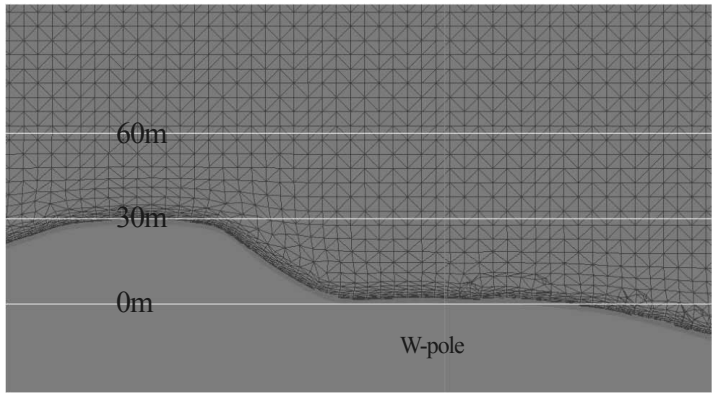

（b） キャノピーモデル用(1)

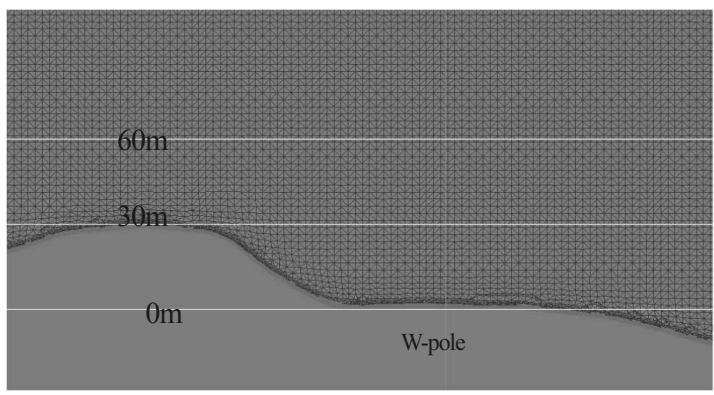

（c） キャノピーモデル用(2)

図 3 観測ポール近傍の格子解像度

図 3 に観測ポール（W-pole）近傍の格子を示す。左側 が風上となっており，W-pole は尾根の風下になっている。
図中の数值は観測ポールが立っている場所からの高さを 表す。上記で生成した壁関数型の格子では全体的に格子 が粗く, 風上の尾根からの剥離等が十分に再現されない 可能性が考えられたため, 地表面近傍にキャノピーモデ ルを導入し, 観測ポール近傍の格子をさらに細かくした。 観測ポール周りを $5 \mathrm{~m}$ 格子幅（キャノピー用(1)）とした ものと，さらに細かく $2.5 \mathrm{~m}$ 格子幅（キャノピー用(2) としたものを生成した。また，キャノピーモデルの場合 には地表面境界条件を non-slip とするため, 最下層の格 子を地表面鉛直方向に 3 分割している。キャノピーモデ ル用格子の床面近傍の色を変えている部分がキャノピー 層である。

(2) 計算概要

解析にあたっては, OpenFOAM 1.7.1 を使用し, 乱流 モデルとしてLES（pisoFoam : 標準スマゴリンスキーモ デル)を用いる。流入面には, 地形計算用に作成した Lund 型流入変動風の滑面用（粗度区分 II相当）を用い，時々 刻々変動する風速時刻歴波形を与える。

地表面を壁関数とする場合には，滑面対数則（LES 用 標準ツールである壁関数) および $\mathrm{z} 0$ 型対数則の 2 種類を 用いる。Z0 の設定にあたっては，陸地及び海面を一様な 值（海: 0.0002, 陸地 : 0.8）とした場合 ( $\mathrm{z} 0$ 一様) と, $100 \mathrm{~m}$ メッシュ土地利用情報に対応した值とした場合 (z0 土地利用)について解析を実施し，その違いを比較した。

今回の計算で用いるキャノピーモデルは(1)式のよう にナビエ・ストークス方程式に速度に対応した抗力項を 付加した形のものである。(2)式が植栽の抵抗を表すもの となっており，3つのパラメータであらわされるが，今 回の計算では植栽の分布・種類等の詳細な情報が分から ないため, 地表面に一様に一定厚さのキャノピー層を与 えることとした。また，(2)式のパラメータの詳細もわか らないため 3 つ係数を掛け合わせたものを 1 つ抗力 係数と考え全領域に同じ值を与えた。值とキャノピー層 の厚さに関しては, テスト計算で森林に対応した $\mathrm{z} 0$ 型対 数則と同等の境界層が生成される值を用いた。

$$
\begin{aligned}
& \frac{\partial \rho u_{i}}{\partial t}+\frac{\partial \rho u_{j} u_{i}}{\partial x_{j}}=-\frac{\partial p}{\partial x_{i}}+\mu \frac{\partial^{2} u_{i}}{\partial x_{j} \partial x_{j}}+F_{u, i} \\
& F_{u, i}=-\rho C_{f} A \eta \sqrt{u_{j}^{2}} u_{i}
\end{aligned}
$$

$C_{f}$ : 抗力係数, $A$ : 葉面積密度, $\eta$ : 緑被率 
（3）地表面境界条件の影響 ${ }^{1)}$

地表面に粗度効果がある場合とない場合の比較を行う ため壁関数を用いた 3 ケースの計算結果の比較を行う。

図 4 は標高 $300 \mathrm{~m}$ の断面の瞬間風速分布である。流入 から入ってくる, 変動成分が計算対象地点付近まで流下 することが確認できる。滑面対数側と $\mathrm{z} 0$ 型対数側の比較 では, z0 型対数側を用いたものの剥離に伴う低風速領域 が広くなっている。z0については, 山岳地であるため森 林で一様とした場合も土地利用データを用いた場合もあ まり違いは見られない。滑面との比較から, 粗度効果を 地表面に入れることによって複雑地形による剥離の性状 が異なることが確認される。

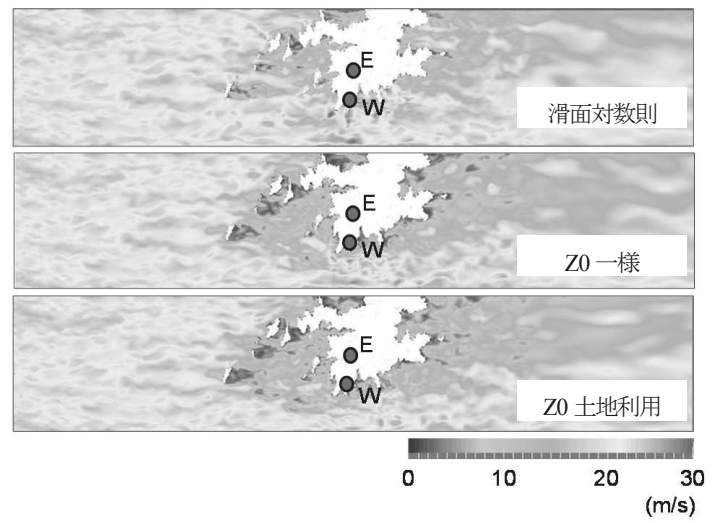

図 4 地表面粗度の違いによる瞬間風速分布の比較

図 5 に解析領域の中央断面（ $\mathrm{y}=0 ）$ における流入から $2 \mathrm{~km}, 4 \mathrm{~km}, 6 \mathrm{~km}$ およびE-pole 地点（流入から約 $10 \mathrm{~km}$ ）の 平均風速と乱流強度の鉛直プロファイルの計算結果を示 す。流入面から $4 \mathrm{~km}$ までは, 海上となっておりプロファ イルの形状に大きな違いが見られない。陸地に入って 1 〜 $2 \mathrm{~km}$ の流入面から $6 \mathrm{~km}$ の場所では, $\mathrm{z} 0$ 型対数則と滑 面対数則で平均および変動のプロファイルの形状に違い が見られる。この部分は海から流入してすぐの場所であ り, それほど地形が複雑ではないため, 床面境界条件に $\mathrm{z} 0$ 型対数則を用いた効果が顕著に現れていると考えら れる。流入面から $10 \mathrm{~km}$ の位置では，いくつもの尾根を 越えて気流が到達する場所であり, プロファイルの形状 が複雑地形の形状によって決定されている可能性が考え られる。しかし, 地表面境界条件により違いが見られて おり, 地形の複雑さだけで平均風速や乱流強度のプロフ アイルが決定されるわけではないといえる。後で説明す る W-pole では, 風上側の尾根からの剥離の影響を強く受 ける地点にあり，剥離等の性状に対しては床面境界条件 が顕著であるとも考えられ, 地表面境界条件の設定は実
際に近いものに設定することが重要であり，キャノピー モデル等も有効であると考えられる。
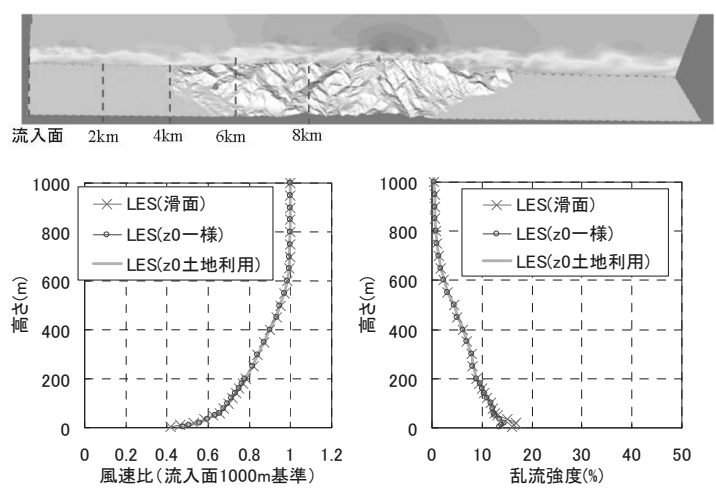

(a) 流入から $2 \mathrm{~km}$
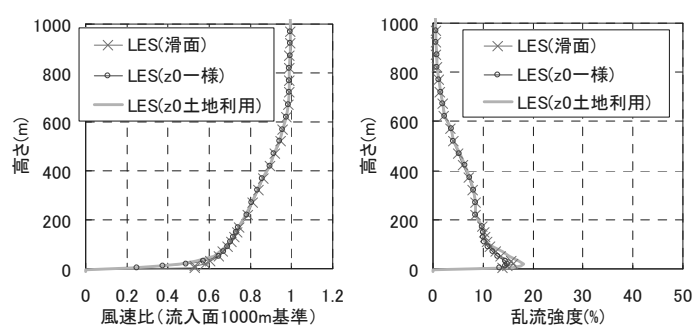

(b) 流入から $4 \mathrm{~km}$
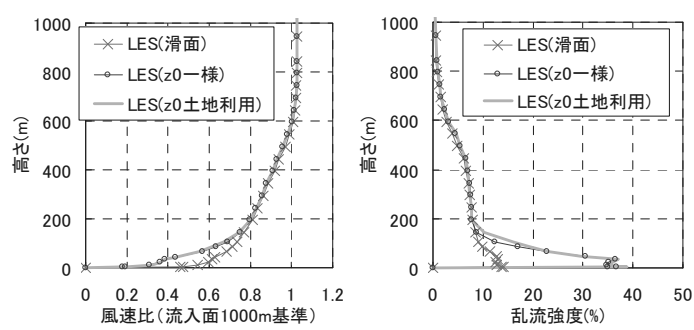

(c) 流入から $6 \mathrm{~km}$
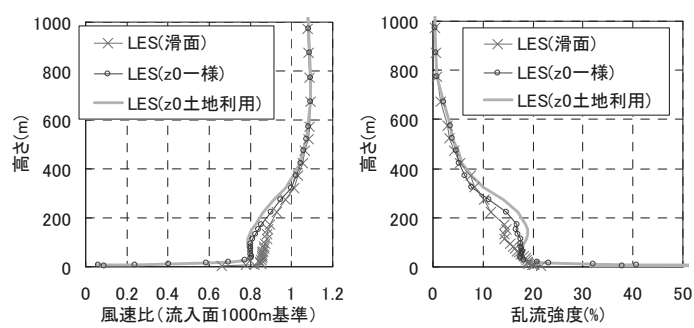

(d) 流入から $10 \mathrm{~km}$

困 5 接近流の鉛直プロファイルの変化

図 6 に計算結果と強風イヴェント時の観測データの平 均風速と乱流強度の鉛直プロファイルの比較を示す。平 均風速については水平方向のスカラー風速をE-pole の最 上部のスカラー風速で基準化した值としている。合わせ 
て観測ポール近傍の地形の状況を示す。どちらの観測点 も風向 NNW に対しては尾根を越えた流れがあたる部分 となっており, ポールの下部は尾根のウエイクに入るも のと考えられる。E-pole では, 尾根の頂部に近く風速が 下がっている部分がかなり低い部分となっているが，風 速が下に行くほどやや低くなる傾向は z0 型刘数則を用 いた場合のほうが良く合っている。乱流強度については 観測と計算が良く合っている。W-pole では, 前方の尾根 からの剥離の影響で下部の風速が大きく減少し, 乱流強 度が大きくなっている。計算では, 滑面対数側を用いた ものでは下部での傾向は明確に出ていないが, $\mathrm{z} 0$ 型対数 則を用いると下部での減速効果が観測以上に強く出てい る。風速が低くなる分, 乱流強度も大きめになっている。 定性的な傾向は $\mathrm{z} 0$ 型対数則を用いることで, 平均風速・ 乱流強度ともに近くなっているものと考えられる。
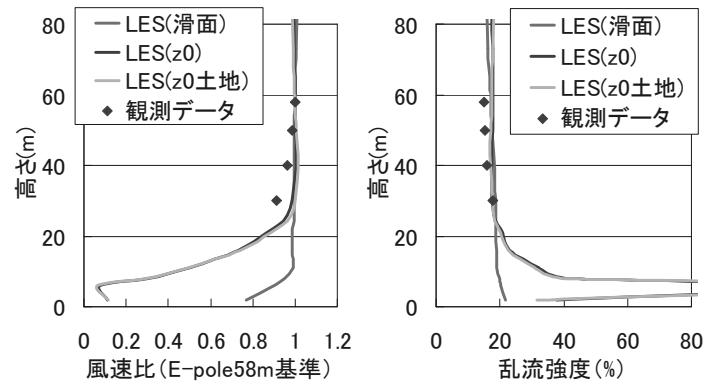

(a) E-pole
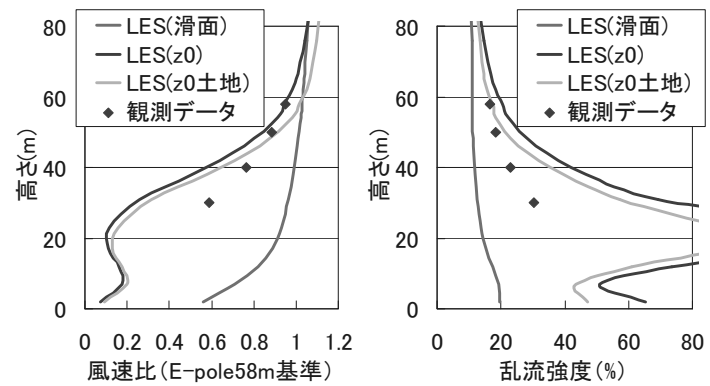

(b) W-pole

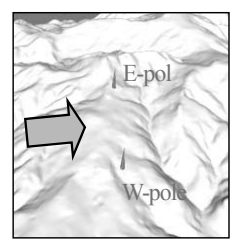

(c) 観測ポール周辺の地形の状況

図 6 観測ポールでの実測と計算結果の比較

(4) 格子解像度の影響 ${ }^{2)}$

計算概要のところで説明したように, 尾根からの剥離
の影響を詳細に再現できるようにさらに細かな格子を適 用するため, 地表面境界条件にキャノピーモデルを適用 し，格子分割が対数則で限定されないようにした計算を 実施した。図 7 にW-pole 近傍 (図 3 に示した格子部分に 対応）における平均風速分布の比較を示寸。 $\mathrm{z} 0$ 型対数則 は前節で示した z0 土地利用の結果である。

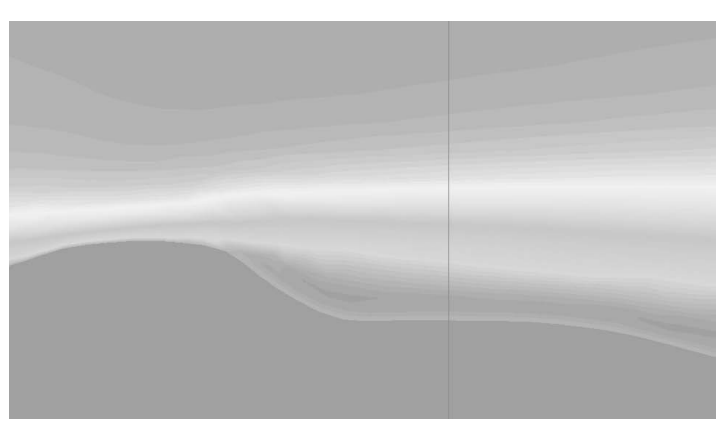

(a) z0 型対数則

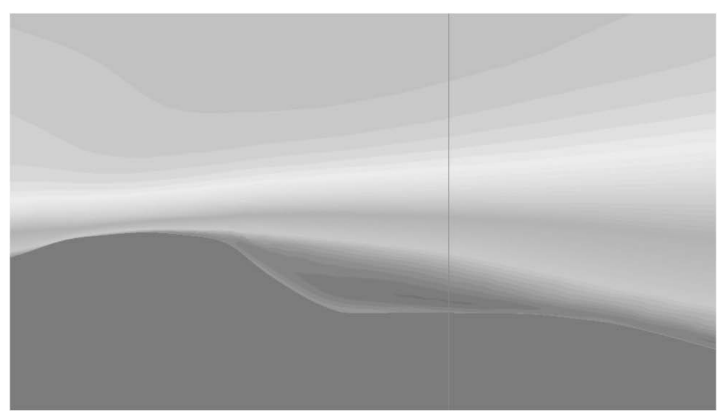

（b）キャノピーモデル(1)

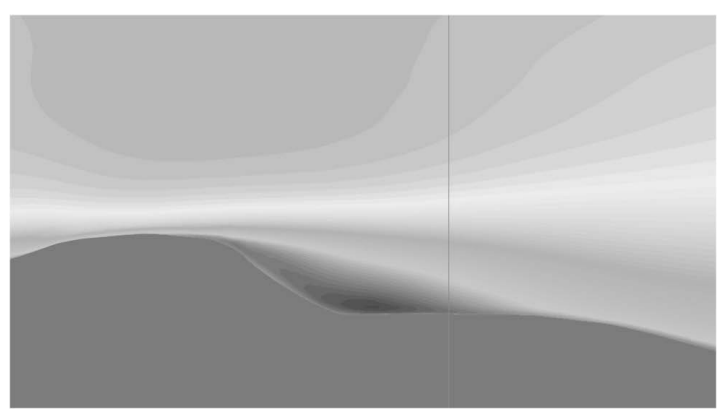

(c) キャノピーモデル(2)

図 7 格子解像度による平均風速分布の比較

$\mathrm{z} 0$ 型対数則に用いた格子は地表面付近で約 $10 \mathrm{~m}$ サイ ズの格子で形成されている。キャノピーモデル(1)では, 地表面付近を $5 \mathrm{~m}$ サイズを基準に格子を生成し，地表面 に沿った層格子を再分割することでキヤノピー層に 5 層 程度の格子が入るようにしている。キャノピーモデル(2) 
では，観測ポール周りの格子解像度をキャノピーモデル (1)の 2 倍（基本格子サイズ $2.5 \mathrm{~m}$ ) としたものとなってい る。流れの状況では, 剥離に伴う低風速領域が, キャノ ピーモデルを用いて格子解像度を上げたものほど地表面 に近づいている。

図 8 に観測ポール位置での特定強風イベントにおける 観測データと計算結果の鉛直プロファイルの比較を示す。 平均風速は観測ポール最上部（高さ $58 \mathrm{~m}$ ) の值で無次元 化している。E-poleではどの結果も実測とほぼ対応して いるが, W-pole ではキャノピーモデル(2)の結果が最も観 測結果と対応しており, 剥離等の挙動を正確に表現する ためには十分な解像度が必要とされると考えられる。
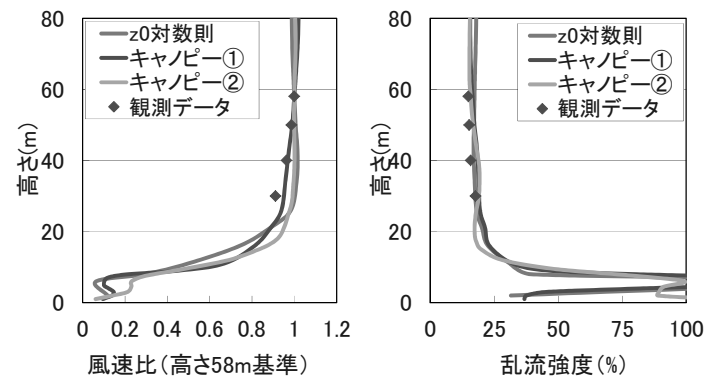

(a) E-pole
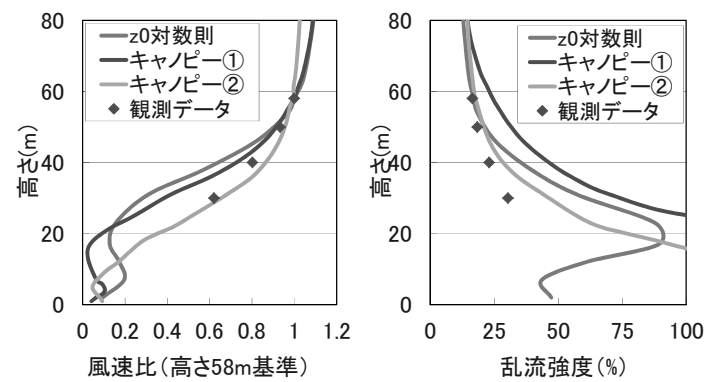

(b) W-pole

図 8 観測ポールでの実測と計算結果の比較

今回の計算では, 風洞実験相当のレイノルズ数で実地 形の計算を実施している。レイノルズ数が上がると，乱 流境界層の対数則領域が地表面に近づくため, 高レイノ ルズ数の計算を実施すれば壁関数による計算であっても 剥離を再現するのに十分な格子解像での計算が可能だと も考えられる。ただし，レイノルズ数を上げた場合に乱 流現象を解くために十分な格子解像度が得られるか等の 課題は残る。格子数や計算時間を考慮すると, キャノピ 一モデルを適用することが現段階では有効な方法ではな いかと考えられる。
（5）流入変動風の影響 ${ }^{3)}$

流入変動風の効果を明確にするため, 流入境界が薩摩 川内市の市街地となっており, その風上には山地（複雑 地形)が続いている風向 ENE についても計算を実施した。 解析領域の設定方法, 格子の生成方法・計算手法は風向 $\mathrm{NNW}$ の場合と同様である。地表面境界条件には z0 土地 利用の壁関数を用いた。

流入面には，地形計算用に作成した Lund ${ }^{4}$ 型流入変動 風 5)を用い, 時々刻々変動する風速時刻歷波形を与える。 用いた流入変動風は, 滑面上に発達したものと（flow-S : べき指数 $\alpha=0.15$ ） と粗面上に発達したもの（flow-T : べ き指数 $\alpha=0.27 ） の 2$ 種類とする。また, 比較用に粗面上 に発達したものと同じ平均風速プロファイルをもち乱れ のない気流（flow-T-nt）を流入としたケースについても 計算を実施する。なお，今回の計算で用いた流入変動風 の境界層厚さは, flow-S で 600m, flow-T で 800m とした。

図 9 は標高 $300 \mathrm{~m}$ の断面の瞬間風速分布である。 flow-S および flow-T では流入から入ってくる変動成分が計算 対象地点付近まで流下寸ることが確認できるが，

flow-T-nt では地形の風上側ではほとんど変動が見られな い。地形の後ろの風速分布ではどれも似たような分布形 となっているが, 流入の平均風速がほぼ等しい flow-T と flow-T-nt を細かく比較すると，地形による剥離等による 減速域の大きさに違いが見られる。乱れのない flow-T-nt の場合に減速域が大きくなる傾向がある。
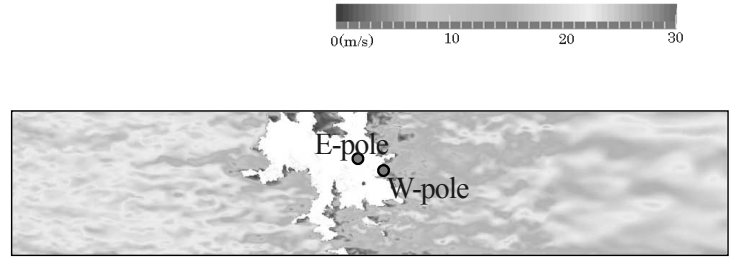

(a) Flow-S

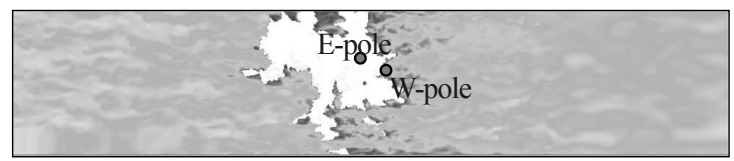

(b) Flow-T

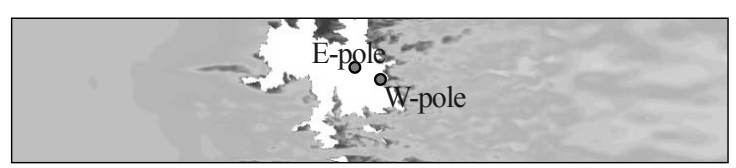

(c) Flow-T-nt

図 9 流入変動風による平均風速分布の比較 
図 10 に解析領域の中央断面（ $\mathrm{y}=0)$ における流入から $2 \mathrm{~km}$ 毎の平均風速と乱流強度の鉛直プロファイルを示寸。 流入面では平均風速プロファイルは多少の勾配の差はあ るがほぼ同じであるが, 乱流強度が Flow-T が Flow-S よ り大きくなっている。Flow-T-nt では, まったく乱れがな い。流入から $1 \mathrm{~km}$ は平坦であり, $1 \mathrm{~km} \sim 3 \mathrm{~km}$ の範囲には テーパーを着けているため, 地形の影響はほとんどない が地表面粗度 $\mathrm{z} 0$ は反映されている。よって, 地表面近傍 において流入気流を作った状態より粗度が大きくなる

Flow-S の場合に変化が見られる。流入から $4 \mathrm{~km}$ の部分で は, Flow-T-ntでは, 床面摩擦による乱れが生じるため平 均プロファイル・乱流強度に大きな変化が見られる。

Flow-S と Flow-T の地表面近傍では, 地表面粗度の影響 で分布が決定されるようになってきているため, ほぼ同 じ分布となっているが，高さ $200 \mathrm{~m}$ 以上の上空では流入 で入れた乱れの影響で Flow-T の乱流強度が高い状態が

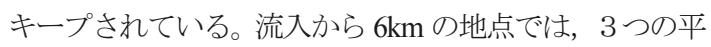
均プロファイルがほぼ同じ状態となっているが,

flow-T-nt の乱流強度が小さい。Flow-S と Flow-T の乱流 強度は高さ $300 \mathrm{~m}$ 程度まで一致してきている。流入から 8kmの地点では, Flow-T-nt の平均プロファイルの形状が 大きく異なる。これは, 乱れが小さいことにより他の場 合と地形による剥離の状況が異なっていることによって 生じていると考えられる。Flow-S と Flow-Tでは, 地表 面に近い部分の形状はほとんど同じとなってきており, 地表面粗度の効果によって乱れが決定されているため, 地表面に近い部分から同じような気流になってきている ものと考えられる。これらのことから, 流入で入れる変 動風の影響によりプロファイルが変化することがわかっ た。勾配をあわせた乱れのない気流では, $8 \mathrm{~km}$ 程度の吹 走距離では，異なった気流のままで異なった鉛直プロフ アイルのままであったが, 乱れ・勾配が異なる気流であ っても合理的に乱流境界層の乱れを持つ流入変動であれ ば，今回程度の吹走距離を確保寸れば地表面から $200 \mathrm{~m}$ 程度の範囲までは同じ気流が生成されることがわかった。 複雑地形上の気流には, 複雑地形の形状 - 地表面粗度等 の影響も大きいが，流入に与える乱れの影響も大きいこ とが確認された。

図 11 に計算結果と観測データの平均風速と乱流強度 の鉛直プロファイルの比較を示す。観測データについて は, 強風時のデータと比較するということで, 平均風速 $9 \mathrm{~m} / \mathrm{s}$ 以上のデータの平均とした。平均風速については水 平方向のスカラー風速を W-pole の最上部のスカラー風 速で基準化した值としている。W-poleにおいては, 平
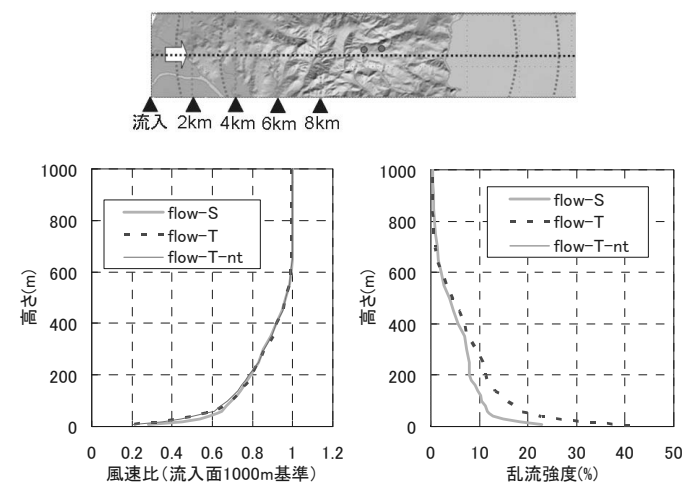

(a) 流入面
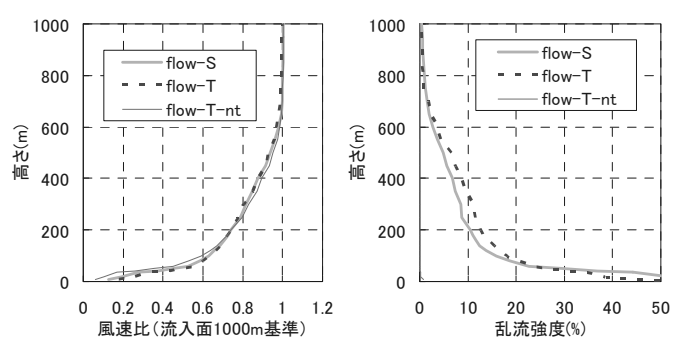

(b) 流入面から $2 \mathrm{~km}$
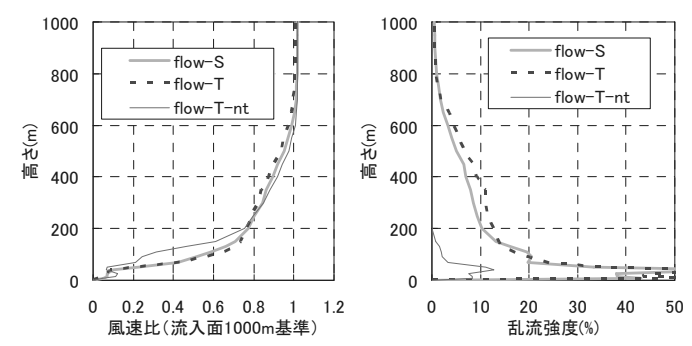

(c) 流入面加 $4 \mathrm{~km}$
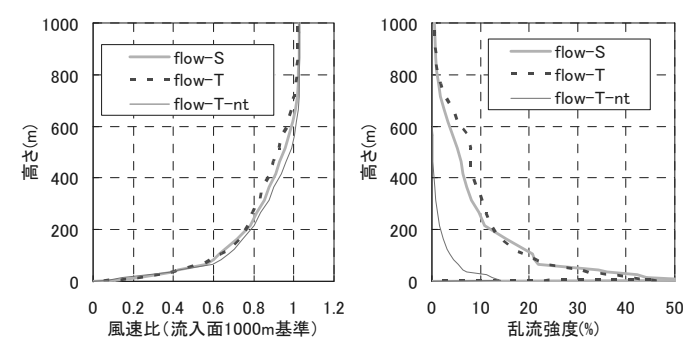

(d) 流入面加 $6 \mathrm{~km}$
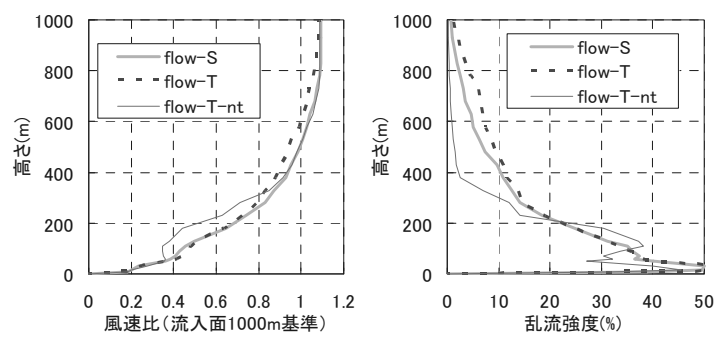

(e) 流入面から $8 \mathrm{~km}$

図 10 流入変動風による鉛直プロファイルの比較 
均風速のプロファイルは, 観測と計算結果でよく一致し ており，計算結果も3つの気流ともよく一致している。 乱流強度については，観測に比較して計算結果は大きく 出ているが, 分布の形状は似ている。E-poleでは, 計算 結果に差が見られるが, 值的には Flow-T の結果が近くな っている。乱流強度については, 観測に比較して計算結 果は大きく出ているが, ある高さで乱流強度が小さくな る分布の形状が再現されているものと考えられる。
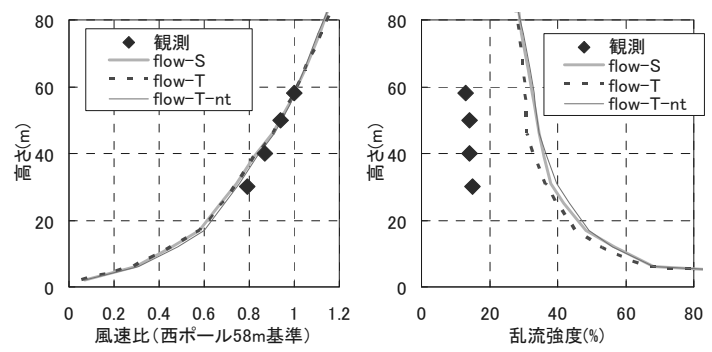

(a) W-pole
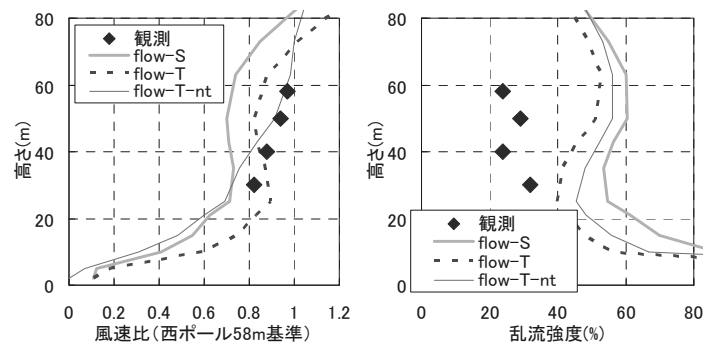

(b) E-pole

図 11 観測ポールでの実測と計算結果の比較

図 10 の地形図から見てわかるように, 観測ポールの位 置は最も高い山の風下となっている。風上側の山塊は, 解析領域のスパン方向全域にわたっているが，今回の計 算では側面の境界条件を slip としている。この影響で, 風上側の山塊から作られた乱れが観測ポール部分に集ま ることから乱流強度が解析領域全体的に高くなってし合 ったのではないかと考えられる。このように複雑地形を 再現して計算する場合には, 解析領域の取り方について 検討を深めることが今後の課題である。

(6) まとめ

非構造格子を用いた実在複雑地形周りの LES を実施

し，以下のような知見が得られた。

・地表面粗度の影響は流れ場の生成や, 剥離の性状に大 きく寄与する。

・地形からの剥離であってもその性状を再現するために
は十分な格子解像度が必要とされる。

・複雑地形上の流れであっても, 流入で与える変動の影 響は大きく, 適切な流入変動風を流入境界に与える必要 がある。

謝辞

本研究は国土交通省の実施する平成 24 年度建築基準 整備促進事業の一環として実施している事業のうち「風 圧力, 耐風設計等に関する基準の合理化に資する検討委 員会」の成果の一部である。複雑地形における観測デー 夕については NEDO 次世代風力発電技術開発 (基礎・応 用技術研究開発）事業より提供を受けた。ここに感謝の 意を表する。

参考文献

1) 丸山 勇祐, 田村 哲郎, 岸田 岳士, 「実在複雑地形周 りの風の流れの L E S 一乱れに与える地形の影響に 関する考察一」, 日本流体力学会年会 2013 講演論文 集, (2013)

2) 丸山 勇祐, 田村 哲郎, 岸田 岳士, 「実在複雑地形周 りの風の流れの LES一流入変動風の影響に関する考 察一」, 第 27 回数值流体力学シンポジウム B09-2, (2013)

3) 丸山 勇祐, 田村 哲郎, 岸田 岳士, 「実在複雑地形周 りの風の性状に関する LES 一地表境界処理・格子 解像度の影響一」, 日本建築学会 2014 年度大会 (近 畿) 学術講演梗概集, (2014)

\section{3 鹿児島串木野 : WRF・一般座標系 LES}

(小野佳之・榎木康太)

(a) 単純地形を対象とした風洞実験結果との比較 地形を対象とする気流解析においては起伏や地表面粗 度を適切にモデル化することに加え, 複雑地形による剥 離や循環領域等の気流性状を高精度で予測可能な計算手 法を用いることが重要である。ここでは，一般座標系と 非構造格子系のLES ソルバを用いて粗面を有する 3 次元 孤立峰を対象とした解析結果を紹介寸る。

(1) キャノピーモデルによる粗度のモデル化

検証対象は，粗度区分 III に相当する粗面を有する 3 次元孤立峰を再現した石原ら ${ }^{1)}$ の風洞実験(峰高さ $\mathrm{H}=40 \mathrm{~mm})$ である。風洞実験において粗面の効果は森林を 模した人工芝によりモデル化されている。LES 解析にお いて地表面粗度のモデル化にはキャノピーモデルを用い 
ており, キャノピーモデルの抵抗係数 $C_{f}$ は一般的な森林 の值である 0.2 , 葉面積密度 $a$ を $1.0 \times 10^{3} \mathrm{~m}^{-1}$ と設定し, そ れぞれ地表面から人工芝の毛足高さである $5 \mathrm{~mm}$ の範囲 に分布させている。なお, 粗度による抗力のみを考慮し, サブグリッドスケールの乱れに関するモデル化は行って いない。

\section{(2) 構造格子と非構造格子の比較}

図 1 に解析格子の外観と解析に用いた変動流入風の鉛 直分布を示す。この検証例では，構造格子用ソルバと非 構造格子用ソルバによる解析結果の違いを検討するため に, 非構造格子用ソルバの解析では, 図 1(a)の構造格子 ソルバ用の構造格子を, 非構造格子用ソルバに合わせた 形式に変換し，計算格子として使用している。最小格子 幅は水平方向約 $0.07 \mathrm{H}$, 鉛直方向約 $0.025 \mathrm{H}$ である。流入 面には実験流入気流に合わせ片岡ら ${ }^{3)}$ の方法と粗面吹走 により生成した変動成分を持つ流入変動風を作成し適用 した(図 1(b))。なお，非構造格子ソルバとして OpenFOAM $^{4)}$ Ver. 2.2.2 の非圧縮 NS の LES ソルバである pisoFoam にキャノピーモデルを実装して使用した。

図 2 には, 解析領域の中心を通る主流方向鉛直断面に おける風洞実験の結果と両ソルバによる解析結果を示す。 すべての值は $z=7 \mathrm{H}$ における風速の主流成分 $u_{\mathrm{ref}}$ で規格化 されている。(a) 平均風速の主流方向成分 $u$ および (b) 鉛 直方向成分 $w$ に関して両ソルバで解析された值の差はほ とんど認められない。風洞実験の值と比較すると両ソル バとも後流循環域のキャノピー層頂部付近における主流 方向と逆方向の流速 $u$ を若干強めに評価していることが わかる。 $w$ 成分の解析結果に関しては両ソルバとも実験 值とよく一致している。一方，(c)（e)に示した無次元化 された各風速成分の標準偏差 $\sigma_{u}, \sigma_{v}, \sigma_{w}$ に関しては, 孤立 峰後流部においてソルバ間で差異が認められる。まず, $\sigma_{u}$ の特徵的な分布である $x / \mathrm{H}=2.5, z / \mathrm{H}=0.75$ 付近における 変曲点が, 非構造格子用ソルバでは再現されていない。 次に， $\sigma_{v}$ に関しては，風洞実験において $2.5 \leqq x / \mathrm{H} \leqq 3.5$, $z / \mathrm{H}=0.5$ 付近の範囲で認められる極小值が, 非構造格子用 のソルバでは明確には確認されないが，構造格子用のソ ルバでは再現されている。最後に， $\sigma_{w}$ に関しては， $\sigma_{u}$ 同様に, 峰頂部高さにおいて流下方向に分布する極大值 を両ソルバとも実験值よりも大きく評価する傾向が確認 された。総じて, 構造格子用ソルバの方が実験值の空間 的な分布をとらえているといえる。

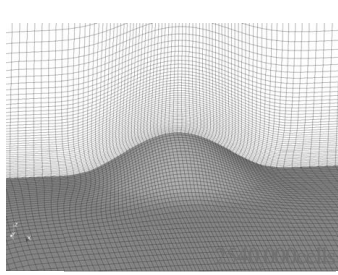

（a）孤立峰周りの格子

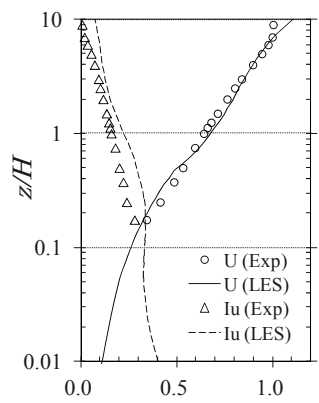

(b) 無次元化流入風

図 1 解析条件 2

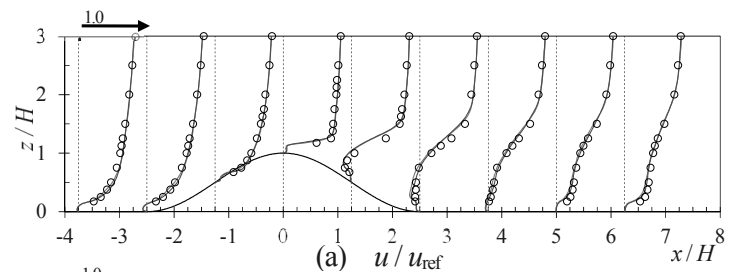

(a) $u / u_{\text {ref }}$
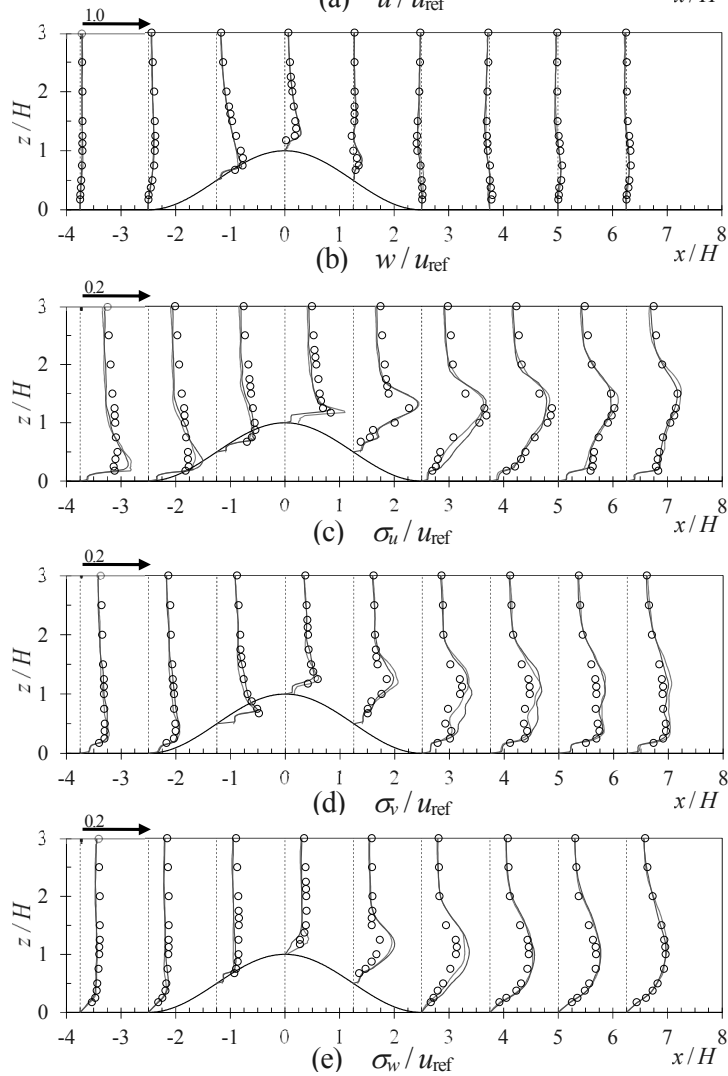

図2 峰中央の鉛直断面における諸量の鉛直分布 ${ }^{2)}$ ○: 風洞実験 ${ }^{1)}$ 一: 構造格子ソルバ一: 非構造格子ソルバ

(3) 地表面のモデル化における課題・展望

上述した単純地形を対象とした解析において，粗面効 果はキャノピーモデルによってモデル化されている。キ 
ヤノピー層内において Smagorinsky 型の乱流モデルを適 用した場合, 計算格子で解像されないグリッドスケール 以下のキャノピー層内粗度要素(木の幹, 枝や葉等) と流 れの相互作用による乱流の生成や散逸の効果が考慮され ないため, 本手法によるキャノピー層付近の乱流性状の 再現性をより詳細に検証する必要がある。また, 構造物 が設置される場所の周辺状況によっては, キャノピー層 の物理過程を考慮する必要がある場合も想定されるため, 今後, 1 方程式型乱流モデルの適用性の検討も行う必要 があると考えらえる.

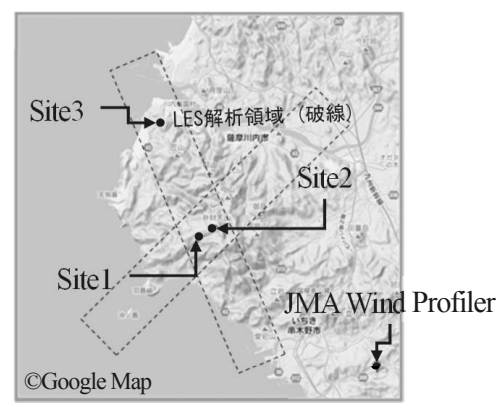

図 3 観測点の位置と LES 解析範囲 $(25 \mathrm{~km} \times 25 \mathrm{~km})^{5)}$

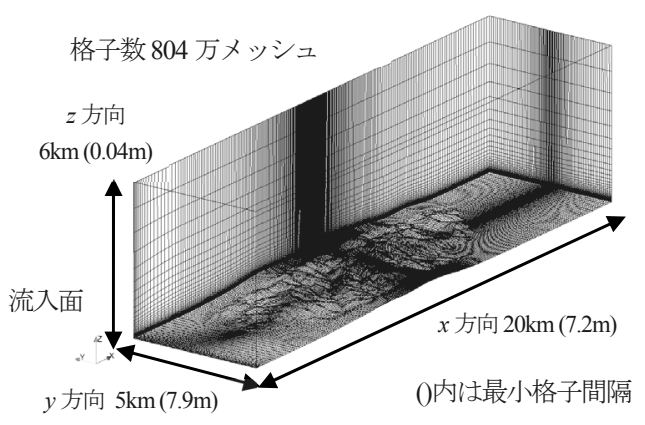

図 4 LES 解析領域 (風向 NNW)

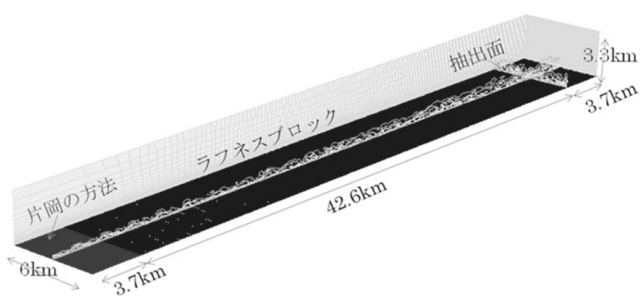

図 5 変動流入風作成のための解析格子

(b) 実地形を対象とした実測結果の風速プロファイルと の比較

実地形を対象とした気流解析への LES 適用事例が増 加しているが, それらの予測の検証は地表面付近の単一,
もしくは近傍の複数観測結果を用いて実施されるケース が多く, 距離の離れた複数の地点の強風予測の検証例は それほじ多くない。LES により解析された気流性状を, 解析領域内の様々な地点において実際に観測された風 向・風速と比較検証寸る必要がある。その検証例として, 実地形(鹿児島県いちき串木野地区)を対象とした一般座 標系の LES による解析結果 5, 6)を示寸。図 3 に解析範囲 と検証に用いた地上観測点(Site1〜3)および気象庁ウィ ンドプロファイラの位置関係を示す。解析が実施された 風向は NNW, SW の 2 風向であり, 図中にLES の解析範 囲を破線で示されている。何れの風向も流入部は海上に 位置する。LAWEPS ${ }^{7}$ のプリ処理機能（国土地理院 $10 \mathrm{~m}$ メッシュ標高 ${ }^{8}$ 利用）を用いて境界面が地形に沿った一 般曲線座標格子を作成した(図 4)。また, 地表面粗度は, 土地利用細分メッシュデータ 9に基づくキャノピーモデ ルにより考慮した。対象地点の周辺は森林に覆われてお り, 森林の粗度高さ $H_{\text {camopy }}$ を $5.0 \mathrm{~m}$, 葉面積指数 LAI を 5.0 と設定し, 次式 $)^{7}$ より葉面積密度 $a$ は $1.0 \mathrm{~m}^{-1}$ となる。

$$
a=\mathrm{LAI} / H_{\text {canopy }}
$$

流入風として, 準周期境界条件を用いた片岡の方法 ${ }^{3}$ により変動風を作成し, その後, ラフネスを配置した粗 面上を発達させたものを用いる 10 )。解析領域, および風 速のコンター図を図 5 に示す。本解析で対象とした変動 流入風は地表面粗度区分 II相当の気流であり, 地表面付 近のラフネス密度が小さく, 境界層の発達に長い吹走距 離を要した。そこで, 計算負荷に配慮し格子解像度を粗 く設定し，ラフネスブロックをキャノピーモデルにより モデル化した。得られた変動風の風速の鉛直分布を図 6 に示す。

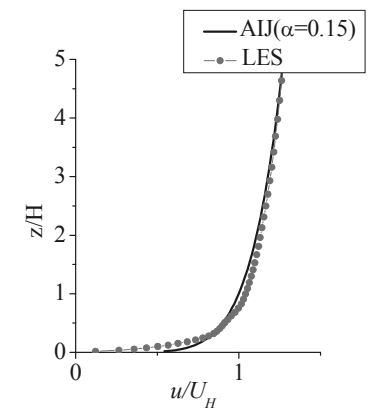

(a) 平均風速

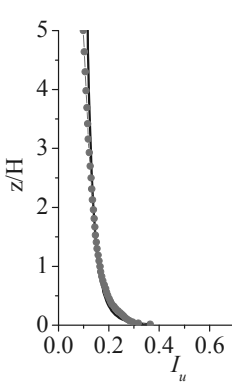

(b)乱れの強さ
図 6 流入変動風 $(\mathrm{H}=75 \mathrm{~m})$ 


\section{（1）平均風速}

図 7 にSite 1 及びSite 2 における風速比の鉛直分布を 示す。図中"観測"は約半年間の観測で Site 1 地上 $58 \mathrm{~m}$ に おいて “検証対象の風向かつ $7 \mathrm{~m} / \mathrm{s}$ 以上の強風” を観測し た際の各観測点の平均値である。また, 風向判定及び風 速比算定の基準点はSite 1 地上 $58 \mathrm{~m}$ の観測点である。LES による風速比は地上付近で若干差異があるが観測值と概 ね対応していることが分かる。図 7 (a) NNW のケースに おいて地上 $60 \mathrm{~m}$ 付近では両地点で風速比がほぼ一致し ている。一方, 図 7 (b) SW 風向のケースでは観測で確認 された両地点間の平均的な差異が, LES でも再現された。 この風向においても LES の地表面付近で実測と差が大 きくなる傾向がある。これらの要因として今回の解析で 用いた土地利用データ自体の精度が解像度 $100 \mathrm{~m}$ 之低い ことが挙げられる。今後より解像度の高いデータを用い ることで改善する可能性がある。

\section{(2) 乱れ強さ}

図 8 にSite 1 及びSite 2 における乱れ強さの鉛直分布 を示す。実測の乱れ強さは, (a) NNW に関しては 2009 年 4 月 25 日, (b) SW の風向に関しては 2009 年 6 月 10 日の温帯低気圧通過時の観測記録から当該風向のデータ を抽出し 10 分間の平均風速と標準偏差より求めた(標本 数 NNW:144, SW:60)。図には乱れ強さの変動範囲(土標準 偏差)も併せて示している。LESによる乱れ強さは, 観測 点位置の 10 分相当の風速時系列データから実測サンプ リング周波数に併せてデータを抽出し, 瞬間風速(2 秒值 相当)を求め, 統計量を算出した。LES に基づき算出した 乱れ強さは Site 2 の地上付近を除き, 実測の変動範囲内 にあることが分かる。Site 2 の地表面近傍において実測の 推定值との差異が大きい原因として風速比の場合と同様 に地表面近傍土地利用データの精度が低いことが挙げら れる。一方, (b) SW のケースは, LES の乱れ強さは実測 に比べ低い傾向を示している。特に Site 2 においてこの 傾向が顕著である。この一因として, 検証対象とした強 風事象の特徵の違いがある。NNW のケースでは風向 NW $\sim \mathrm{NNW}$ 平均風速 $12.9 \mathrm{~m} / \mathrm{s}$ の強風が一日を通じて定常的に 吹いており, 大規模の気象擾乱による大きな風向や風速 の変化は確認されない。一方, SW のケースは平均風速 が $13 \mathrm{~m} / \mathrm{s}$ 以上の強風事象であるものの, NNW のケース とは性状が異なり, 低気圧の通過に伴い $\mathrm{S} \sim \mathrm{SW} \sim \mathrm{W}$ へと 大きく風向が変化し急激に風速が増加するという特徵を 有する。この場合, LES で考慮されない上空の気象擾乱 で生じる乱れや風向の急激な変化に伴い生じる乱れが観

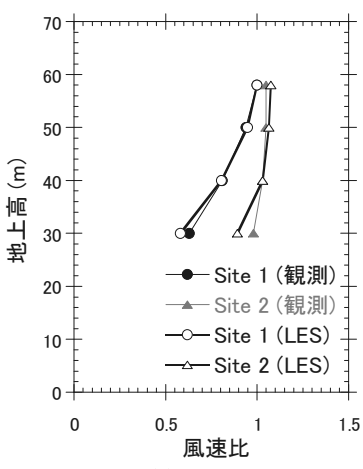

(a) NNW

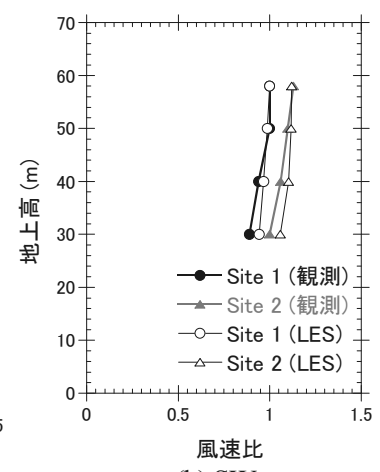

(b) SW
図7 各観測地点における風速比の鉛直分布の

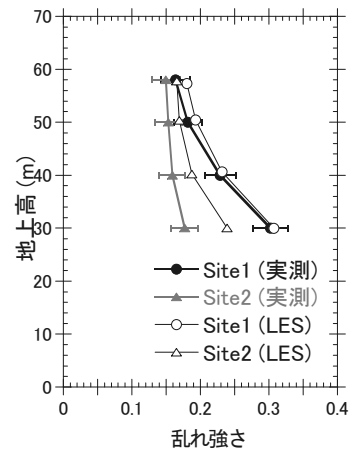

(a) NNW

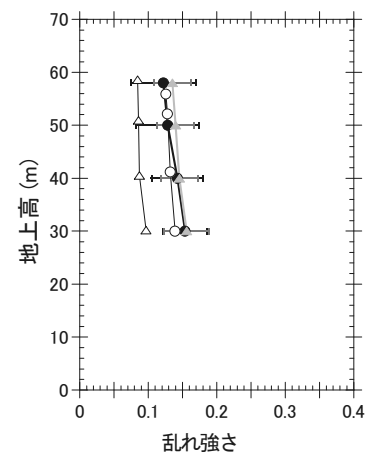

(b) $\mathrm{SW}$
図 8 各観測地点における乱れ強さの鉛直分布の)

測された可能性がある。

（c）実地形を対象とした実測結果の風速の絶対值との 比較

最後に, 実地形上で観測された風速を観測に依らず領 域気象モデルと LES の解析結果を組み合わせることに より予測した例を示す。ここで強風事象の解析に用いら れた領域気象モデルは, 米国国立大気研究センターにお いて開発された Weather Research and Forecasting Ver.3.5 (以下 WRF)である。WRF は地形準拠の乾燥大気 の質量座標系で記述された完全圧縮・非静力学系モデル であり, 運動量保存式, 連続式, 熱力学方程式, ジオポ テンシャル方程式等で構成される。解析に用いた WRF の物理モデル等の解析条件を表 1 に示す。

表 1 気象モデルの解析概要

\begin{tabular}{|c|l|}
\hline 計算期間 & $2011 / 2 / 9-12 \quad$ (4 日間) \\
\hline 釷直格子 & 鉛直 48 層 (最小格子間隔約 50m) \\
\hline 境界層過程 & Mellor-Yamada-Janjic \\
\hline 地表面過程 & Monin-Obukhov (Janjic Eta) \\
\hline
\end{tabular}


この解析では 5 段階の 2 way ネスティングを行ってい る。気象モデルのネスティング範囲を図 9 に示す。最も 外側の計算領域 $\mathrm{d} 01$ はおよそ $2200 \mathrm{~km} \times 2200 \mathrm{~km}$ の範囲で 水平格子解像度を約 $20 \mathrm{~km}$ に設定した。最内の解析領域 $\mathrm{d} 05$ は, $25 \mathrm{~km} \times 25 \mathrm{~km}$ の範囲で水平格子解像度は約 $250 \mathrm{~m}$ である。

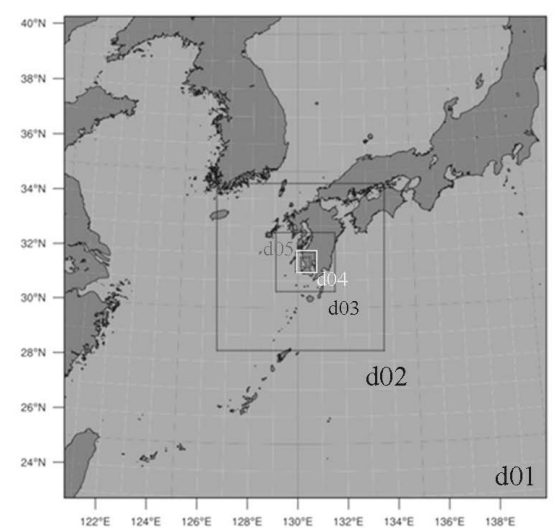

図 9 気象モデルの解析範囲

気象モデルと中立大気を前提とした LES を接続する 際の前提条件としては, 該当地域周辺に LES で解析を行 った風向(NNW)の強風状態が継続していることや大気 境界層が中立状態であること等が挙げられる。図 10 には 強風が定常的に観測された午前 6:00〜8:00 の間に気象庁 ウィンドプロファイラ市来 (位置は図 3 参照)で観測され た各高度の平均風速及び風向 $\left.{ }^{12}\right)$ と WRF の解析值 $(\mathrm{d} 05)$ の 結果を標準偏差と共に示す。図より, 気象モデルで海抜 $1000 \mathrm{~m}$ 以上の風向風速は概小実測とよく対応しているこ とが分かる。標高 $1500 \mathrm{~m}$ 以下では, 境界層風速が約 $22 \mathrm{~m} / \mathrm{s}$ のほぼ一様な上空風が解析されている。また図 11 には, 同時間帯の解析領域の流入部における WRF で解析され た風速の鉛直分布形状を示す。境界層下部の流入部にお いて解析された平均風速の鉛直分布はべき指数が概算で 0.1 から 0.15 程度であり, 粗度区分 II を想定した LES の 流入条件に概ね適合していることが確認された。また, 温位に関しては, 近傍の高層気象観測点である鹿児島地 方気象台におけるゾンデの観測值(2/11 21:00JST と 2011/2/12 9:00JST)とよく対応していることや該当時刻に 解析領域内 $1500 \mathrm{~m}$ 以下では, 概ね温位勾配は小さく熱的 に中立な状態であることも確認している。一方で，風向 に関しては, 下層ではNW から NNW 風向が支配的であ り，LES で想定した NNW 風向に合致しているものの, 上空では南寄りの風向に変化していることがわかる。
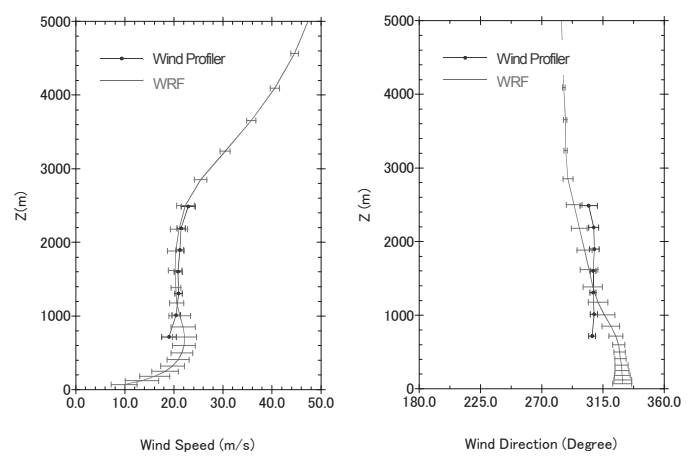

図 10 ウィンドプロファイラ位置における平均速度およ び風向の鉛直分布 $(2 \text { 時間分の } 10 \text { 分值から算出 })^{5)}$
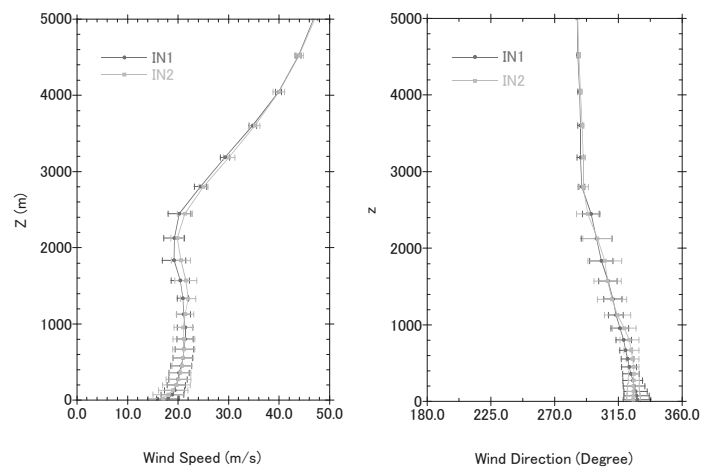

図 112011 年 2 月 12 日 6 8 時の LES 流入地点付近に おける WRF 解析の時間平均值(風速風向)鉛直分布 In1 が流入面の東端部，In2 が西端部に対応。

(2) WRF と LES の接続方法

WRF の解析結果に対して，ある高さにおいて LES で 解析された平均風速と風向を一致させることで, 地上付 近の強風イベント時の風向・風速值が算出される。

ただし, WRF の解析により得られた上空の風向は, 高 さ方向に一定とは限らず，また，対象とする強風イベン 卜の発生期間においても風向は時々刻々変化する。そこ で，ここでは，気象モデルWRF の解析を行い，Site3 及 び Site1 における風向の観測記録より LES を実施した NNW 風向時の時間帯を選び, 強風イベント時の上空風 から LES の解析結果を用いて観測地点における地上付 近の風向・風速を求めた。

気象モデルと LES の接続には以下のような方法がと られている。LES 解析領域内の任意の点 $i$ の風速 $u_{i}$ 及び 風向 $\theta_{i}$ は, 水平距離が最も近い気象モデルの解析格子点 $\left(x_{n p}, y_{n p}\right)$ の高さ $z_{r e f}$ における風速 $u_{W R F, n p}$ 及び風向 $\theta_{W R F, n p}$ を用いて，次式により算出する。 
$u_{i}(t)=\frac{u_{L E S, i}\left(z_{i}\right)}{u_{L E S, n p}\left(z_{r e f}\right)} u_{W R F, n p}\left(t, z_{r e f}\right)$

$\theta_{i}(t)=\theta_{W R F, n p}\left(t, z_{r e f}\right)-\theta_{L E S, n p}\left(z_{r e f}\right)+\theta_{L E S, i}\left(z_{i}\right)$

ここで, $u_{L E S, p}(z)$ は地点 $p$ における LES の解析值, $t$ は時刻である。式(1)は気象モデルの上空解析点の風速を LES の風速鉛直分布にそって地上の解析点へ降ろしてく ることを意味している。また, 式は気象モデルの上空解 析点の風向に対して LES により解析された上空と地上 の地形による風向角の偏差を加えることを示している。

例えば，図 12 において参照高さが $z_{r e f}=z_{1}$ のケース， $z_{r e f}=z_{2}$ のケースは，それぞれで以下のように WRF と LES は接続される。

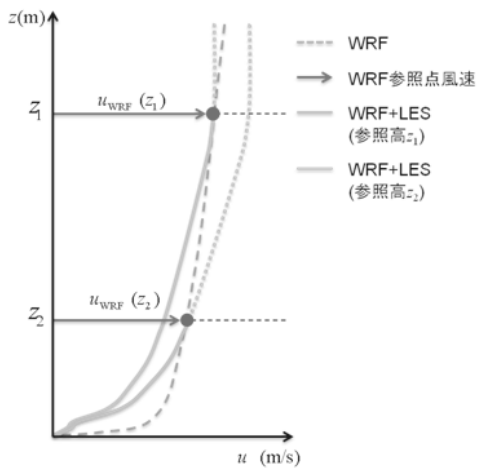

図 12 気象モデルと LES の接続の概念図

図 12 のように, 参照点 $z$ の選択により, 気象モデル の風速值と参照点高さ以下の接続により算出された風速 值も変化することがわかる。

\section{(3) 風速の絶対值予測}

図 13 に 2011 年 2 月 12 日午前 6 時から 8 時の時間帯の Site 1 の観測高 $30 \mathrm{~m}, 40 \mathrm{~m}, 60 \mathrm{~m}$ における観測值, WRF の上空風速を LES から得られた風速の鉛直分布により 補正して求めた推定值を示す。参考としてWRF の地上 付近解析值も図示されている。図 13 の推定值は, 上空風 の解析精度が確認された高さでかつ, LES で解析された 風速の鉛直分布から地形影響が顕著に確認されず，境界 層外にあると判断された高さである海抜 $1000 \mathrm{~m}$ をWRF の参照格子点として LES による上空と地上の風速比を 適用したものである。WRF の地上付近風速は, 過大評価 の傾向にある。LES の風速比による補正值は, 観測高 $40 \mathrm{~m}$ と $60 \mathrm{~m}$ において観測とよく対応している。一方，高さ $30 \mathrm{~m}$ では実際より低く風速が見積もられ, LES の地表面
付近の精度に準じた結果になっていることがわかる。

図 14 は, Site 3 における風向と風速の時系列を示す。 風向に関する量は白抜きのマーカーの系列に対応し, 風 速に関する量は黒色のマ一カーの系列に対応する。風向 に関しては，上空風の気象モデルの解析值に基づく LES による補正值, 地上付近の気象モデルの解析值とも観測 值の傾向に近いことがわかる。また，Site3 の LES によ る風速の補正值は観測值に近い值を示しており，地上付 近の観測值から Site1 から上流約 $8 \mathrm{~km}$ と離れた場所に位 置する Site3 においても, LES により推定された風速比 が広域にわたる風速の絶対值推定に適用できる可能性が 示された。

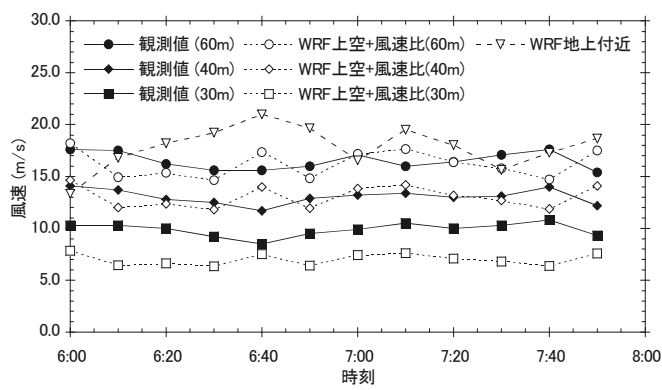

図 13 Site1 における風速の時系列 5)

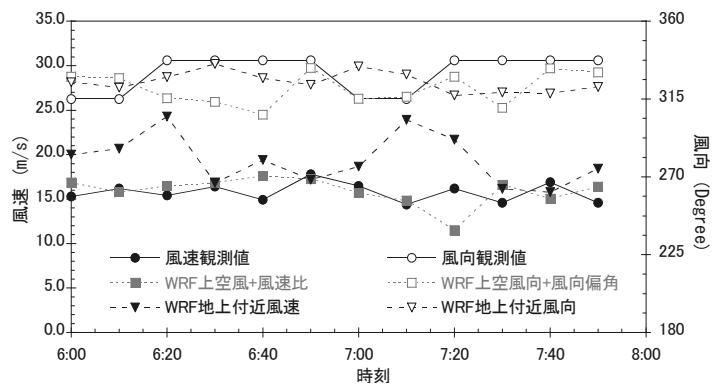

図 14 Site3 における風速と風向の時系列 5)

参考文献

1）石原，日比，「急峻な山を越える乱流境界層に関する 実験的研究」, 第 15 回風工学シンポ予稿集, pp. 6166, (1998)

2)榎木, 小野,「異なるソルバによる単純地形周りの気 流解析」，建築学会学術講演梗概集, (2014)

3) 片岡, 水野,「流入変動風を用いた三次元角柱周り流 れの計算一平均速度分布を与条件とした流入変動風 の作成方法について一」, 第 12 回 数值流体力学シ ンポジウム, pp. 173-174, (1998)

4) OpenFOAM, http://www.openfoam.org

5) 榎木, 小野, 「風速の絶対值予測を通じた気象モデル 
と LES による複雑地形影響評価手法の検証」，風工 学会誌, Vol.38, No. 2, pp. 229-230, (2013)

6) 榎木, 小野,「複数地点の観測を用いた LES による複 杂隹地形影響評価手法の検証」, 建築学会学術講演梗概 集, pp. 95-96, (2013)

7) NEDO 局所的風況予測モデル LAWEPS, http://app2.inf oc.nedo.go.jp/nedo/top/top.html.

8）国土交通省国土地理院，基盤地図情報，http://www.gsi. go.jp/kiban/.

9）国土交通省，国土数值情報, http://nlftp.mlit.go.jp/ksj/ind ex.html.

10) 小野，田村，「粗面を有する三次元丘陵地まわりの強 風乱流への LES の適用」, 日本建築学会構造系論文 集, 606 号, pp. 73-80, (2006)

11) Skamarock, W. C., et al., "A Description of the Adv anced Research WRF Version 3", National Center for Atmospheric Research Technical Note, NCAR, (2008)

12) 京都大学グローバル大気観測データ気象庁データ, http://database.rish.kyoto-u.ac.jp/arch/jmadata.

\section{4 白滝WF : 非構造格子 LES}

(野津剛)

本節では複数の観測データの同時取得が可能なウイ ンドファーム ${ }^{1)}$ を対象に LES を実施し, 観測データと比 較・検討することにより LES の予測精度を検証し, 実地 形問題への適用性を確認したものを報告する。ここでは 特に, 格子解像度や地表面粗度, 流入風の乱れの有無が 解析結果に与える影響について言及する。

\section{(1)解析条件}

解析対象は，山口県下関市豊北町の白滝山にあるウイ ンドファームである。図 1 に示すように, ウインドファ 一ムは海岸から $10 \mathrm{~km}$ 程度離れた山間部に位置し, 海か ら徐々に地形が複雑かつ険しくなっている。風車は標高 $400 \mathrm{~m}$ から $600 \mathrm{~m}$ 程度の険しい山地の尾根上に 20 基が配 置されており (図 2), ナセル上（地上高さ $85 \mathrm{~m}$ ) に風速 計が設置されている ${ }^{1)}$ 。解析風向は, 海側から吹く風 (北 東風）を対象とする。

解析領域は, 図 1 , 図 3 に示すように風上側に海を含 むよう主流方向に $25 \mathrm{~km}$, 直交方向に $8 \mathrm{~km}$, 鉛直方向に $8 \mathrm{~km}$ である。流出境界付近には比較的高い山が存在する ので, 境界面から数 $\mathrm{km}$ の位置で山をなだらかに変形さ せている。計算はOpenFOAM（Ver. 1.7.1）を用いて行な っており, 乱流モデルは標準 Smagorinsky モデル, モデ

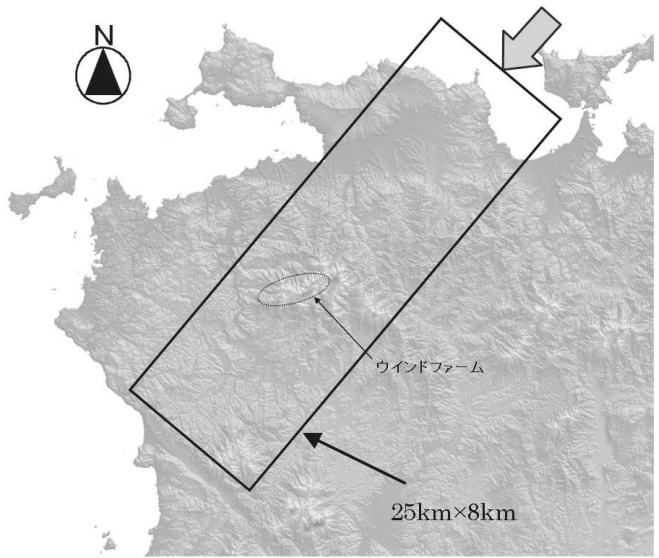

図 1 ウインドファームと周辺環境

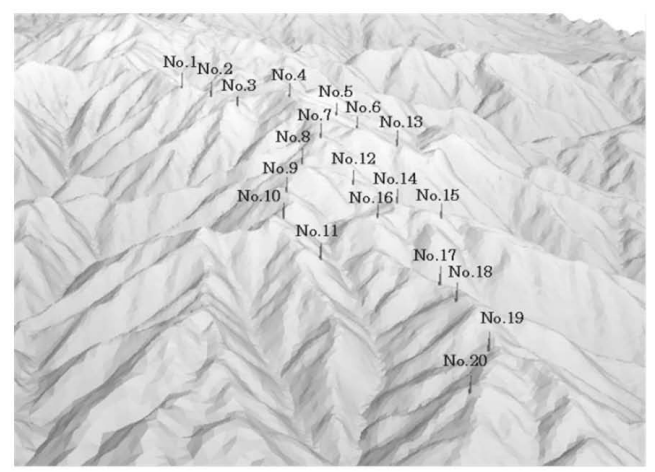

図 2 風車配置状況

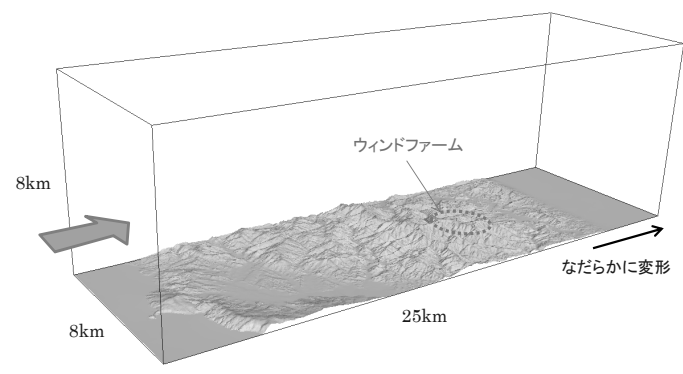

図 3 解析空間

ル定数 Cs は 0.1 とした。

計算格子は非構造格子を用いており，図4 に示すよう に格子解像度を変えた 2 パターン作成している。最小水

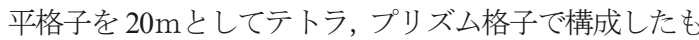
のを格子粗のケース, 最小水平解像度を $10 \mathrm{~m}$ として六面 体・四角錐・四面体格子で構成したものを格子密のケ一 スとする。両ケースともに地表面近傍には境界層セルを を挿入している。一方，地表面境界条件については，滑 面対数則および $\mathrm{z} 0$ 型粗面対数則の 2 ケースとし, 粗度長 $\mathrm{z} 0$ は海水域で $0.0002 \mathrm{~m}$ ，森林で $0.8 \mathrm{~m}$ とした。 
解析ケースは表 1 に示寸ように, 格子解像度（最小水平 格子), 地表面の境界条件, 流入風の乱れの有無を変化 させた全 5 ケースである。Case1〜4の流入風は海上から 来る風を想定していることから, Lund の手法 ${ }^{2)}$ を用い て計算した滑面の乱流境界層（べき指数 $\alpha=0.15$, 境界層 厚さ $\delta=600 \mathrm{~m})$ を用いている。図 5 に流入気流の鉛直プ ロファイルを示す。なお, Case5 は乱れの無い一様勾配

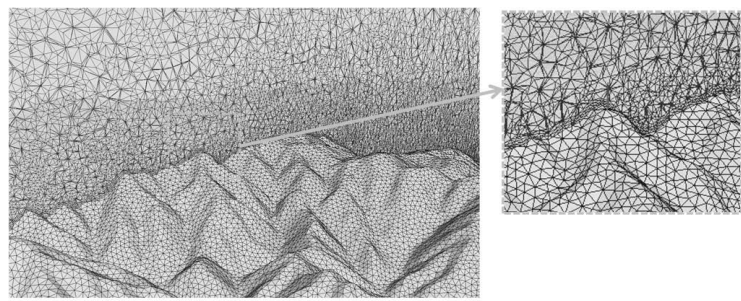

(a) 格子粗（最小水平格子 $20 \mathrm{~m}$ )

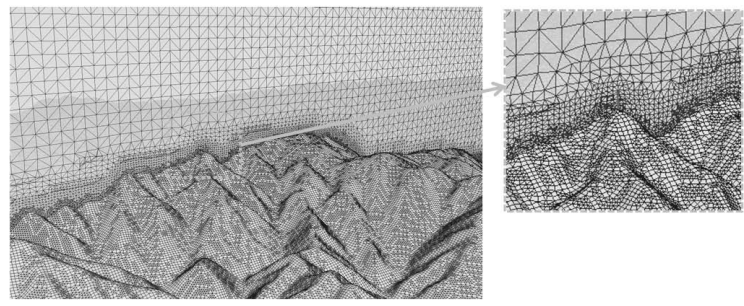

(b) 格子細（最小水平格子 $10 \mathrm{~m}$ )

図 4 ウインドファーム近傍の計算格子

流を流入風として与えている。

表 1 解析ケース

\begin{tabular}{|c|c|c|c|}
\hline 解析ケース & 最小水平格子 & 地表面の境界条件 & 流入風 \\
\hline Case 1 & $20 \mathrm{~m}$ & 滑面対数則 & 乱流境界層 \\
Case2 & $20 \mathrm{~m}$ & z0型粗面対数則 & 乱流境界層 \\
Case 3 & $10 \mathrm{~m}$ & 滑面対数則 & 乱流境界層 \\
Case 4 & $10 \mathrm{~m}$ & z0型粗面対数則 & 乱流境界層 \\
Case 5 & $10 \mathrm{~m}$ & z0型粗面対数則 & 勾配流 \\
\hline
\end{tabular}

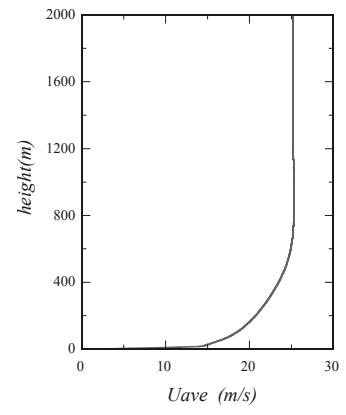

(a) 平均風速

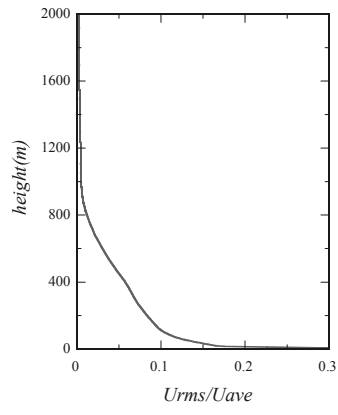

（b）乱れ強さ
図 5 流入変動風の鉛直プロファイル
(2)解析結果

格子解像度の影響

図 6 に水平断面における瞬間風速コンター図（高さ $400 \mathrm{~m}, \mathrm{z} 0$ 型粗面対数則) を示寸。格子解像度が高い結果 では, 風上の流入風の風速変動が維持されて流下してい ることが確認できる。また, 山表面近傍の風速低下の範 囲が比較的小さくなっていることがわかる。

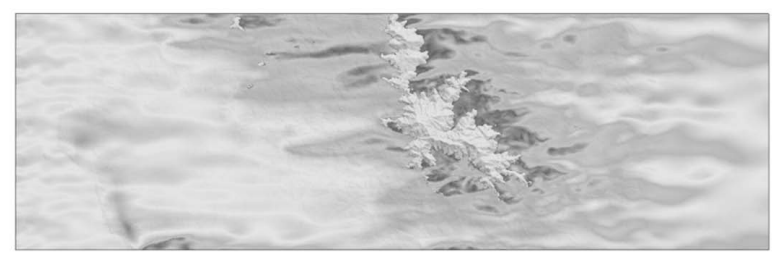

（a）格子粗（最小水平格子 $20 \mathrm{~m}$ ）

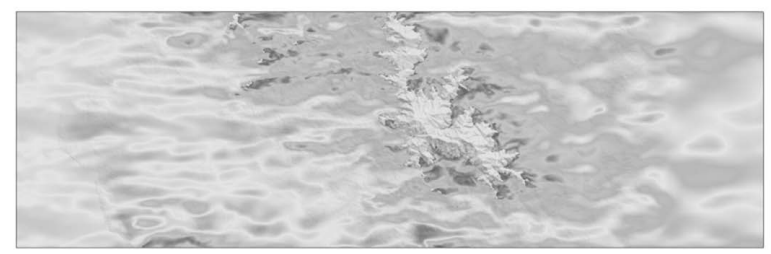

(b) 格子細（最小水平格子 $10 \mathrm{~m}$ )

図 6 高さ $400 \mathrm{~m}$ における瞬閒風速コンター図

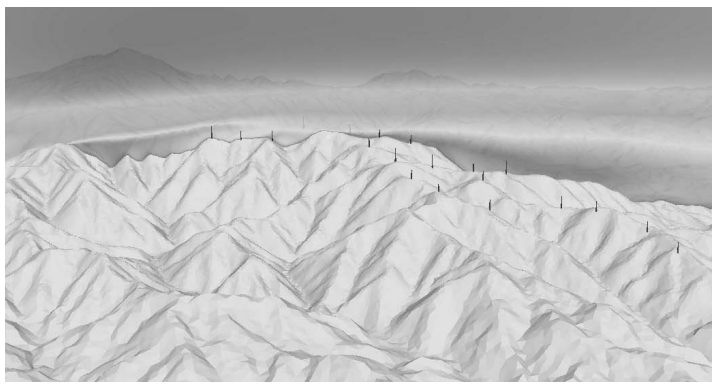

（a）格子粗（最小水平格子 $20 \mathrm{~m}$ )

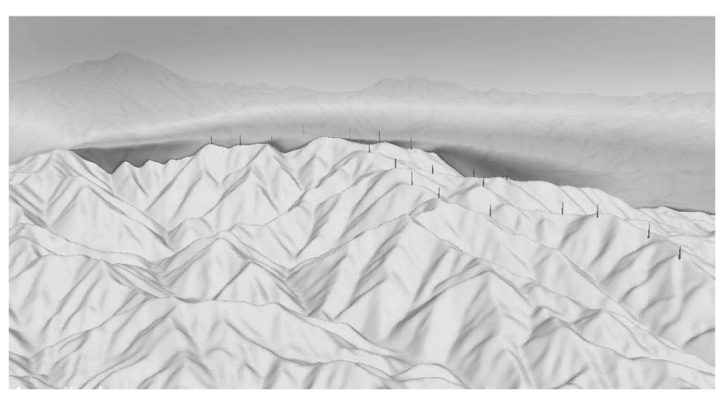

（b）格子細（最小水平格子 10m）

図 7 ウインドファーム近傍の平均風速コンター図 
図 7 にウインドファーム近傍における鉛直断面の平均 風速コンター図を示す。格子解像度が低いケースでは, 地表面近傍の速度低減範囲が高い位置まで見られる。一 方, 格子解像度が高いケースでは, 山背後の速度低減範 囲が狭くなっている。また，格子解像度を高くすること により, 山形状をより滑らかに表現していることも確認 できる。

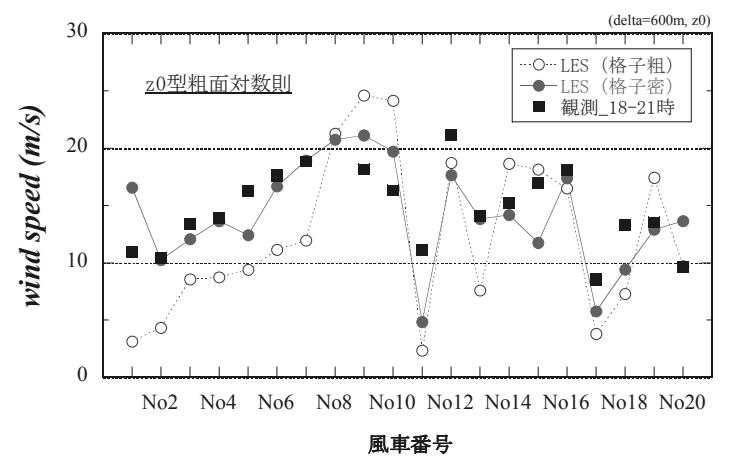

(a) 平均風速

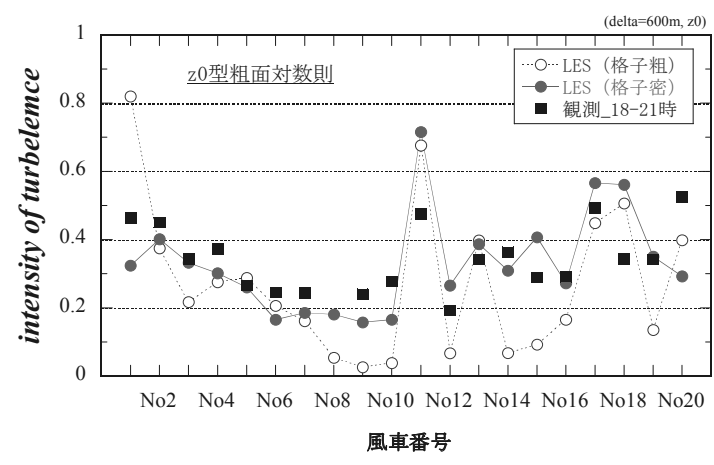

（b）乱れ強さ

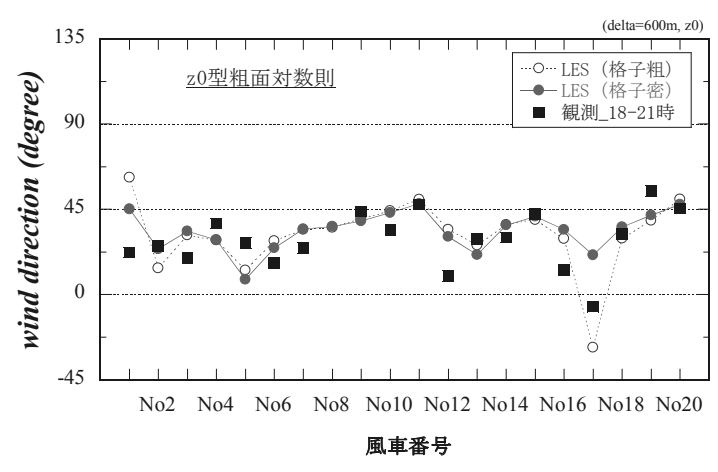

(c) 平均風向

図 8 LES と観測值との比較（格子解像度の影響）

図 8 に平均風速, 乱れ強さ, 平均風向について観測值 と比較して格子解像度の影響をそれぞれに示す。格子解
像度が高くなることで，ナセル高さにおける平均風速， 乱れ強さともに観測值に近づくことがわかる。ただし， 平均風向については，あまり差は見られない。

\section{地表面粗度の影響}

図 9 にウインドファーム近傍の鉛直断面における平均 風速コンター図を示す。 $\mathrm{z} 0$ 型粗面対数則のケースでは, 地表面近傍の速度低減範囲が高い位置まで見られる。一 方, 滑面対数則のケースでは, 山背後の速度低減範囲が 狭くなっていることが確認できる。その結果, 風車位置 No.11 に着目すると, z0 型粗面対数則のケースでは完全 に山の後流域に埋没する様子が見られる。

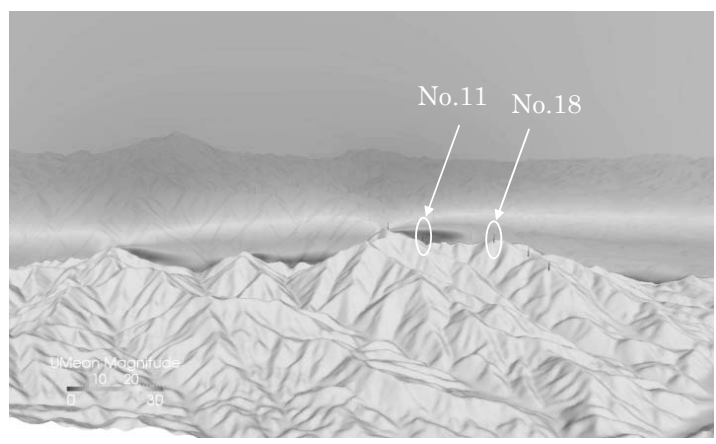

(a) 滑面対数則

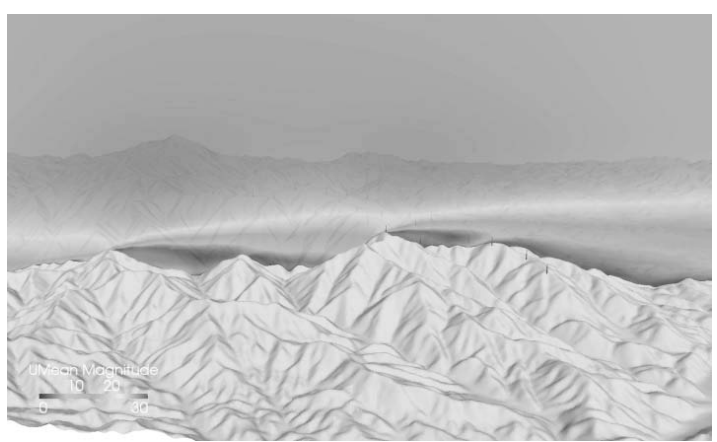

(b) $\mathrm{z} 0$ 型粗面対数則

図 9 ウインドファーム近傍の平均風速コンター

図 10 に風車位置No.18における風速および風向の時刻 歴波形を示す (位置は図 9 参照)。No.18 は，風上にある 山の後流域に入るか入らないかの微妙な位置にあるため, 壁面境界条件の影響を非常に強く受ける。そのため, 山 の後流域が広くなる $\mathrm{z} 0$ 型対数則を用いたケースでは, 風 速変動および風向変動が大きくなっている。

図 11 に平均風速, 乱れ強さについて地表面粗度の影響 を示す。 $\mathrm{z} 0$ 型粗面対数則を用いることで, 平均風速が全 


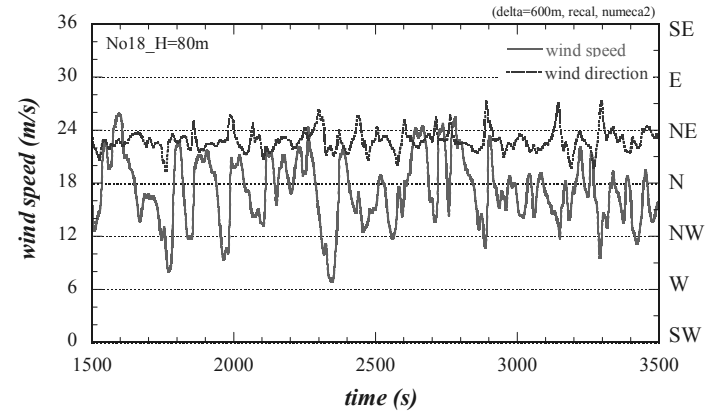

(a) 滑面対数則

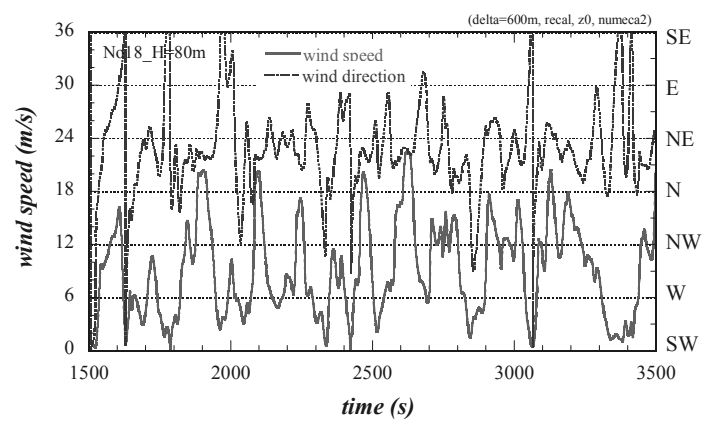

(b) $\mathrm{z} 0$ 型粗面対数則

図 10 風速・風向の時刻歴波形（風車位置 No.18)

体的に低下寸るとともに乱れ強さが大きくなる傾向が見 られ，観測值と良い対応を示すことが確認できる。

図 12 (a) (b) にz0 型粗面対数則を用いた場合の地表 面高さ $60 \mathrm{~m}$ における平均風速コンター図と図中に示寸 ライン上での標高の分布をそれぞれ示す。尾根に沿って 平均風速の速い領域が存在するのが見られる。

図 13 に図 12 に示寸 2 地点 $(\mathrm{A}, \mathrm{B})$ における平均風速 の鉛直分布を示す。標高が徐々に上がっている尾根付近 では地表面近傍まで増速傾向にあり, 尾根の背後の標高 の低い部分では上空まで速度欠損が大きくなる傾向にあ る。

\section{流入気流の乱れの有無の影響}

図 14 に高さ $200 \mathrm{~m}$ における水平断面の瞬間風速コンタ 一図を流入気流の乱れの有無を比較して示寸。流入風に 乱れが無い場合には, 流入境界近傍の山背後の後流域が 非常に長くなっている様子が見られる。流れが解析領域 内部一進むにつれて, 山及によって乱れが生成される様 子が確認できるが，乱れはなかなか発達しない。

図 15 に乱流強度の鉛直プロファイルについて, 流下方 向の変化を示寸。図中の高さは, 山の地表面がゼロにな るように補正している。流入風に乱れが無くとも流下寸

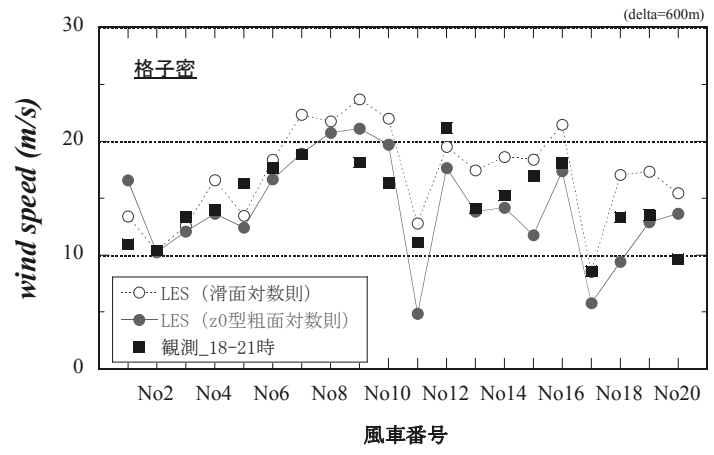

(a) 平均風速

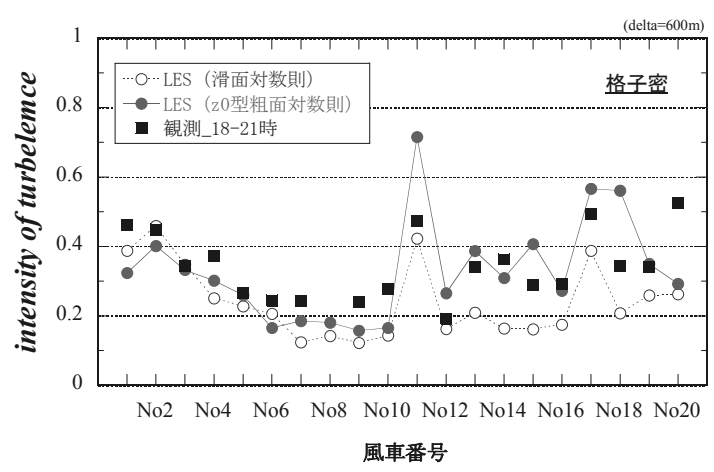

（b）乱れ強さ

図 11 LES と観測值との比較（地表面粗度の影響）

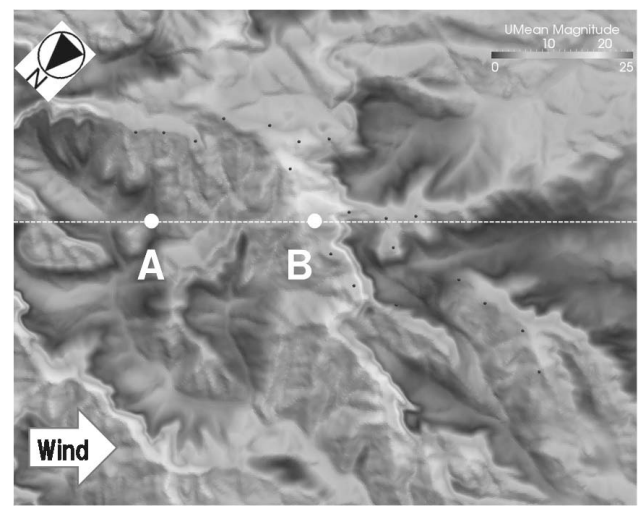

(a) 平均風速

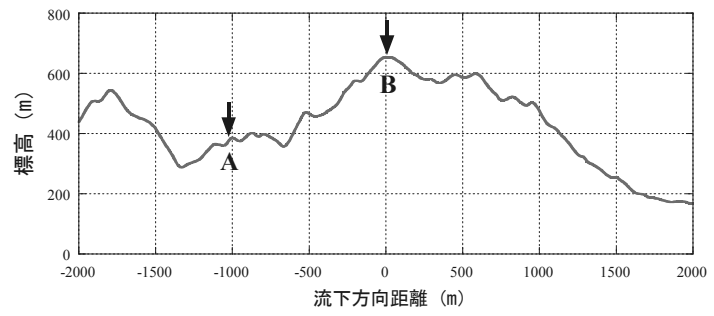

(b) 標高

図 12 地上高さ $60 \mathrm{~m}$ での平均風速コンター図と標高 
るにしたがって乱れは発達するが，上空へは乱れがなか なか発達しないことがわかる。ただし，流入境界から $14 \mathrm{~km}$ 地点の変動成分の鉛直分布については両者がほぼ 一致することが確認できる。

しかし一方で，風車位置によっては変動風のパワース ペクトルに違いが見られる結果が得られた。図16 に示寸 風車位置 No.9 は比較的前方が開けている位置にある風 車のものであるが，流入風に乱れの無いケースでは乱流 境界層を用いたものと比べて低周波成分のパワーが小さ いことが確認できる。 (a) A地点

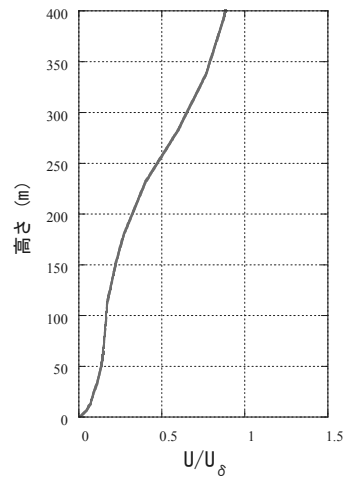

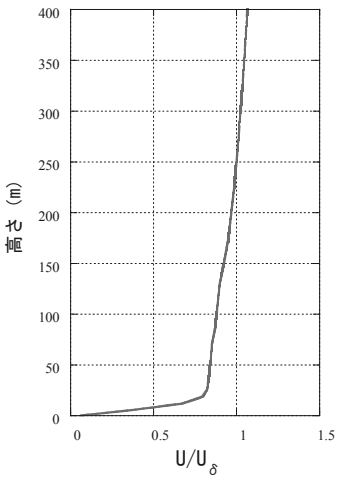

(b) B地点
図 132 地点の平均風速の鉛直分布

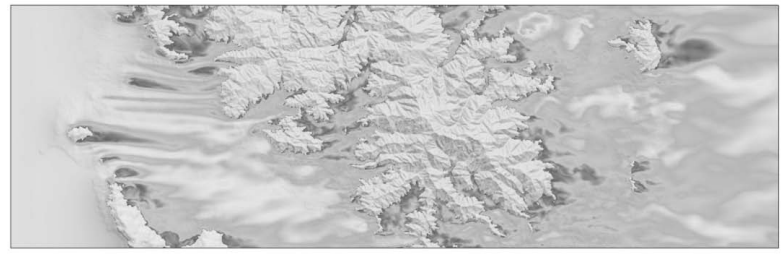

（a）一様勾配流

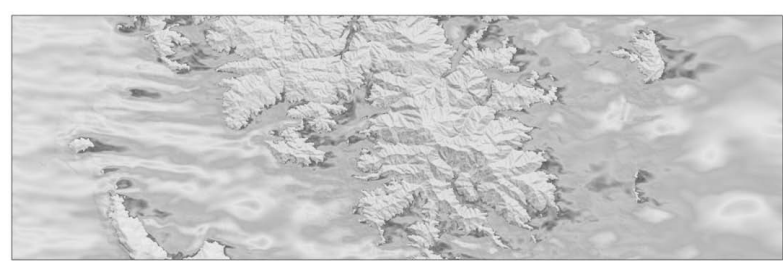

(b) 乱流境界層流

図 14 高さ $200 \mathrm{~m}$ における瞬間風速コンター図

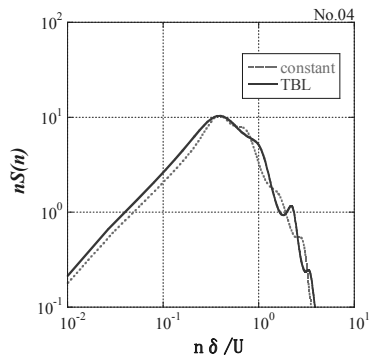

(a) 風車位置 No.4

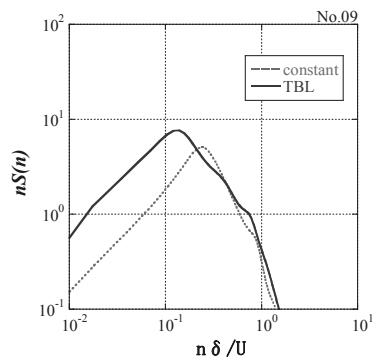

(b) 風車位置 No.9
図 16 風車位置での気流のパワースペクトル
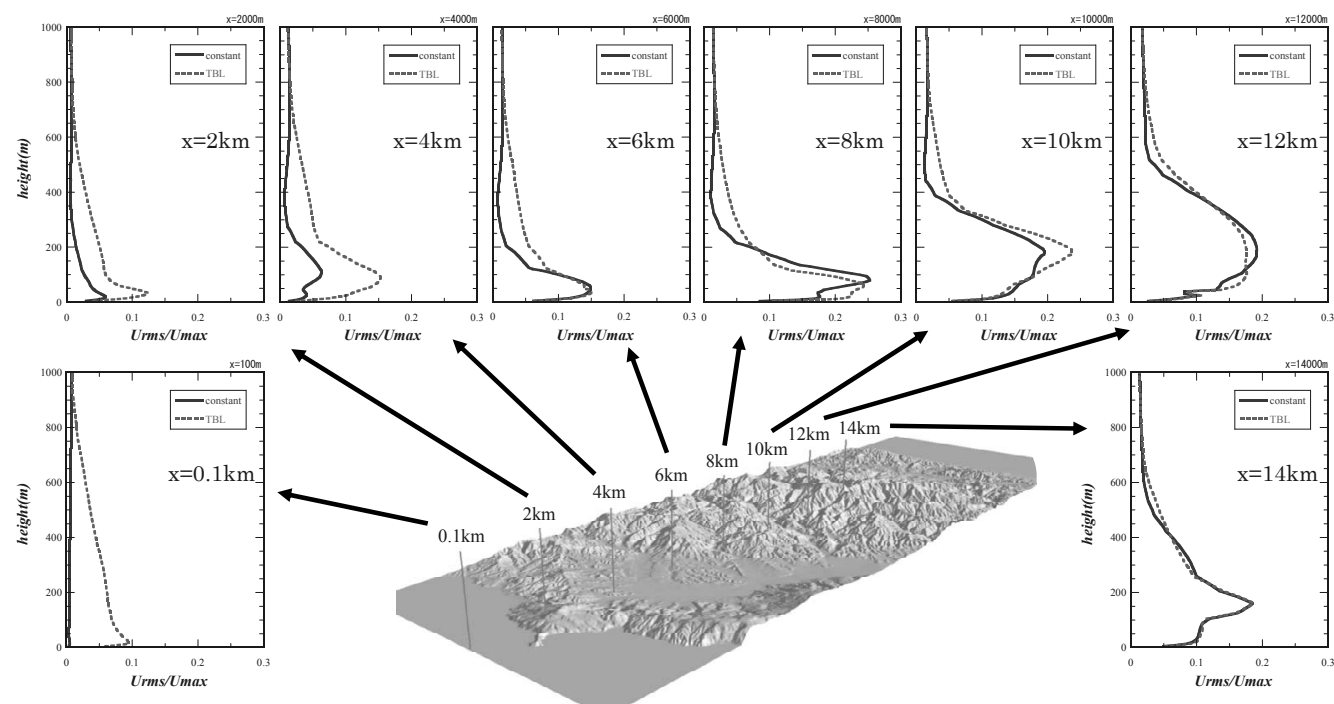

図 15 流下方向の乱流強度の変化の比較 
(3)まとめ

本稿では複数の観測データのある実地形を対象にLES を実施し, 格子解像度や地表面粗度, 流入風の乱れの有 無が解析結果に与える影響を示した。

\section{謝辞}

本研究は, 国土交通省平成 23 年度建築基準整備促進補 助事業での「風圧力, 而風設計等に関寸る基準の合理化 に資する検討」なる研究課題の一環として実施されたも のである。また, 観測データは株式会社きんでんより提 供していただいたものである。ここに謝意を表する。
参考文献

1）丸山, 石川, 内田, 出口, 「メソスケールモデルと LES を用いたウインドファーム周辺の気流解析」, 第 21 回風工学シンポジウム論文集, (2010)

2) Lund T. S., Wu X., Squires K. D., "Generation of turbulent inflow data for spatially developing boundary layer simulation", Journal of Computational Physics, 140,(1998) 